\title{
Filiação consangüínea: da diferença à igualdade e suas conseqüências no Código Civil Brasileiro*
}

\begin{abstract}
Alu ísio Pires de Oliveira**
Sumário: Apresentação; I. Sistema clássico de filiação; 1. Da filiação e suas espécies: 2. Estrutura do sistema de filiação imediatamente anterior à constituição de 1988; 3. Evolução legislativa brasileira em matéria de filiação; 4. Direitos dos filhos legítimos, legitimados e reconhecidos antes da constituição: II. Algumas propostas doutrinárias que antecederam a Constituição Federal de 1988; III. Da percepção de família contemporânea e suas regras constitucionais; IV. Princípio da igualdade; V. Da igualdade na filiação; VI. Efeitos da igualdade de filiação; 1. Premissas dos sistemas; 2. Do parentesco; 3. Espécies de filhos; 4. Da legitimação; 5. Da presunção de paternidade; 6 . Reconhecimento de paternidade; 7. Investigação de paternidade; 8. Da ação de impugnação da paternidade; 9 . Da posse do estado de filho; 10 . Das antigas espécies de filhos: 11. Dos direitos pessoais e patrimoniais de todas as espécies de filhos: Conclusão.
\end{abstract}

\section{Apresentação}

Com o advento da Constituição Federal de 1988, ocorreram notáveis modificações no Direito de Família, alterando-se a base do ordenamento que privilegiava a instituição familiar constituída pelo casamento, em detrimento dos filhos não originados do matrimônio.

Esta concepção tradicional foi derrocada com as disposições constitucionais inovadoras no âmbito da família, sendo relevante, em suma, a ampliação das formas de família para abranger não só o casamento, mas também a união estável e a comunidade formada por um dos genitores e

* Monografia apresentada à disciplina de Direito Civil II. do CPGD/UFPR, sob a orientação do Professor Doutor Luiz Edson Fachin.

** Advogado em Curitiba, mestrando no CPGD/TFPR.

R. Fac. Direito. Curitiba. a.27. n.27. 1992/93. p.141-202 
seus descendentes; ${ }^{1}$ a igualdade entre todos os filhos de direito e qualificações; ${ }^{2}$ a igualdade de direitos e deveres entre homem e mulher na sociedade conjugal ${ }^{3}$ a previsão do princípio da paternidade responsável. ${ }^{4}$

Os corolários constitucionais mencionados representam, desta forma, o filtro pelo qual todas as incursões acerca do direito de família deverão passar, cabendo-nos apreciar suas implicações sobre o vínculo de filiação.

A tarefa, todavia, não é fácil de ser realizada, pois o tradicionalismo inerente às disposições normativas do Código Civil sobre a família e filiação impede o desvencilhamento dos preconceitos ${ }^{5}$ arraigados no saber jurídico.

A exposição a seguir desenvolvida observará uma ordem cronológica dos institutos, levando-se em consideração que, para compreender as implicações do regramento constitucional, é indispensável ter notícia do direito anterior.

Terminada a análise histórica, será a vez de estudar a igualdade genérica e estrita, para possibilitar a apreciação das leis ordinárias poste-riores à Constituição vigente e as implicações no restante do ordenamento jurídico que ainda não foram objeto de disposição legislativa.

Não nos cabe determinar os caminhos que a doutrina e jurisprudência deverão tomar, quanto menos o do legislador, mas não nos omitiremos de fazer sugestões e de enfrentar as inúmeras questões que se originam no plano da igualdade de filiação.

Artigo $226, \S \S 3^{\circ}$ e $4^{\circ}$.

Artigo $227, \S 6^{\circ}$.

Artigo $226, \S 5^{\circ}$.

Artigo $226, \S 7^{\circ}, 1^{\text {a }}$ parte e artigo 229 .

Formação a priori que recobre a realidade com conceitos atualmente inaplicáveis diante das disposições inovadoras da Constituição Federal de 1988. 


\section{Sistema clássico de filiação}

Observando-se os sistemas jurídicos sobre o vínculo de filiação, é indispensável uma análise dos alicerces do ordenamento clássico, pois somente depois de vencida esta etapa, será inteligível a ratio do sistema moderno.

Por conseguinte, o presente capítulo fornecerá os elementos tradicionais e históricos do sistema clássico, devendo a compreensão, todavia, levar sempre em conta o objetivo do nosso trabalho, qual seja, a aplicação da igualdade no campo da filiação.

\section{Da filiação e suas espécies}

Em sentido genérico, pode-se conceituar filiação como sendo o vínculo entre pais e filhos, que provoca efeitos práticos e jurídicos para ambas as partes envolvidas na relação, conectando uma pessoa àquelas que a geraram.

Quando ocorria o nascimento do filho, o direito tratava de classificálo conforme os critérios fornecidos pelo sistema clássico, retirando a possibilidade do recém-nato de se esquivar das conseqüências jurídicas do fato nascimento.

No dizer de Antonio Cicu, ${ }^{6}$ sobre a interferência do direito no fato nascimento, a filiação natural existe sempre nos indivíduos, sendo filhos do pai e da mãe, mas a filiação jurídica visa atribuir efeitos jurídicos à procriação natural, por meio da confirmação da paternidade e maternidade.

Consoante esta concepção, o fato natural da procriação interessava ao direito, apenas quando desse lugar a uma relação social de caráter especial, isto é, ao reconhecer a qualidade de filho legítimo ao ente gerado durante a relação matrimonial dos ascendentes.

Nada impede, entretanto, que a filiação jurídica seja concernente com a filiação biológica ${ }^{7}$ ou, até mesmo, com a filiação sociológica e afetiva. ${ }^{8}$ Mas, no sistema clássico, o privilégio incidia sobre a filiação jurídica, sendo

6 Antonio Cicu. La filiación. Madrid. I,ibreria General de Victoriano Suárez. 1930. p. $123 / 4$.

- Resultante do fato natural da procriação.

8 Fruto do tratamento que os genitores dão ao filho, bem como da imagem apreendida pelo meio social deste relacionamento.

R. Fac. Direito. Curitiba. a.27. n.27. 1992/93. p.141-202 
que muitas vezes, esta intervenção do direito acobertava com verdades fictícias a filiação biológica, ou, senão, deixava distante da visão sócioafetiva.

Neste contexto, o ordenamento jurídico brasileiro anterior à Constituição de 1988 apresentava ${ }^{9}$ diversas espécies de filiação resultantes da interferência do direito sobre o nascimento.

O critério de classificação do sistema clássico atendia à origem constitutiva da filiação, tendo de um lado, o vínculo proveniente da consangüinidade em conseqüência da procriação e de outro, o parentesco civil decorrente da adoção. ${ }^{10}$

No tocante à relação de filiação oriunda da procriação, distinguia-se entre filhos legítimos, legitimados e ilegítimos.

Os legítimos eram aqueles provenientes de uma relação entre marido e esposa na época da fecundação, ou seja, a união dos ascendentes legitimada pelo casamento válido, putativo ou anulável amparado pela boa fé dos genitores, nos termos do artigo 337 do Código Civil Brasileiro. ${ }^{11}$

Quanto aos ilegítimos, eram tidos como produto de uma relação dos pais, sem a existência do vínculo matrimonial.

Ilegítimos naturais designava os filhos nascidos de pais que poderiam se casar, em virtude da inexistência de proibição legal para tanto, mas não o fizeram.

Ilegítimos espúrios, por sua vez, eram os filhos que provinham de uma relação impedida juridicamente entre os genitores, subdividindo-se em adulterinos quando houvesse vínculo conjugal com terceiro que não o outro genitor, classificando-se, ainda, em unilateral a patre ou a matre conforme o genitor casado fosse, respectivamente, o pai ou a mãe, e bilateral no caso de ambos os pais serem casados, mas não entre si, e incestuosos, quando decorressem de genitores em que a relação de parentesco entre eles impedisse o matrimônio dos mesmos.

9 Utilização verbal no tempo pretérito em razão da inaplicabilidade atual destas construções legais e doutrinárias no campo da filiação.

10 Não será versado no decorrer do trabalho sobre a adoção em razão do tema limitar a aplicação do princípio da igualdade de filiação aos filhos consangüíneos.

11 Revogado expressamente pela Lei ${ }^{\circ}$ 8.560, de 29.12.92. 
A filiação incestuosa pode ser subdividida em absoluta, conforme o impedimento para o matrimônio seja entre ascendente e descendente, ou relativa, se na linha colateral.

\section{Estrutura do sistema de filiação imediatamente anterior à Constituição de 1988}

No intuito de possibilitar o entendimento da evolução histórica e legislativa sobre a filiação, a estrutura do sistema de filiação anterior à Carta Magna deve ser analisada em seus pontos principais.

Em primeiro lugar, como núcleo da diferença entre as espécies de filhos, está a presunção de paternidade, a qual opera para facilitar a prova da filiação legítima, tendo uma natureza de presunção intermédia, ${ }^{12}$ ou seja, admitindo prova em contrário, mas nos estritos limites legais, de tal forma que corresponde ao meio encontrado pelo legislador para se esquivar da dificuldade de estabelecer a data de concepção. ${ }^{13}$

Estão englobadas na presunção de paternidade duas outras, quais sejam, a presunção de coabitação dos cônjuges à época da concepção e a presunção de que esta coabitação tenha ocasionado a concepção, em outros termos, a presunção de geração.

O efeito da presunção de paternidade é estabelecer o surgimento do vínculo de filiação, proporcionando imediatamente ao filho legítimo por ela abarcado, diversos direitos em relação aos pais, além de incutir o respeito de terceiros, exonerando o filho de provar a paternidade.

Mesmo que tivesse ocorrido adultério, a presunção operava em favor da legitimidade, desde que, na dúvida, atribuía-se ao pai constituído legalmente a paternidade, supondo-se que o filho da mulher casada tem a paternidade do seu marido.

No que diz respeito à ação de impugnação da paternidade conferida ao marido, era admitida somente se houvesse impossibilidade material de

12 Não se trata de presunção iuris et de iure, diante da possibilidade de prova em contrário. nem de presunção iuris tantum. pois os instrumentos probatórios são rígidos e não permitem a produção livre de provas.

13 Presume-se que o pai é o marido da mãe.

R. Fac. Direito, Curitiba. a.27. n.27. 1992/93. p.141-202 
concepção (por moléstia ou ausência), conforme o artigo 340 de Código Civil.

A legitimidade para propositura da ação tinha exclusividade do pai presumido, com o prazo decadencial exíguo de dois meses, para o pai presente e três meses, para o ausente. ${ }^{14}$

$\mathrm{Na}$ última fase jurisprudencial antes da reforma operada no Direito de Família pela via constitucional, a separação de fato passou a justificar a procedência da ação de impugnação da paternidade.

Sobre a paternidade e respectiva impugnação, a Constituição produziu diversas conseqüências com os novos princípios, como se verá adiante.

A maternidade, ${ }^{15}$ por outro ângulo, obedece ao princípio de que mater sempre certa est, uma vez que no próprio termo de nascimento deve constar a maternidade, declarada segundo a existência da certidão de casamento dos pais, pela própria mãe ou terceiro, atribuindo o oficial uma presunção de veracidade para a declaração recebida, mas, em caso de dúvida, sendo possível a diligência a respeito da veracidade do fato gravidez. ${ }^{16}$

Na hipótese de omissão do nome da mãe no termo de nascimento, possibilita-se a investigação de maternidade, ou se errôneo o registro, pode-se contestar a maternidade alegando a falsidade do termo ou da declaração nele contida.

A legitimação, por sua vez, consistia no meio pelo qual se conferia os benefícios da filiação legítima aos filhos naturais, estabelecendo-se pelo

14 Artigo $178, \S \S 3^{\circ}$ e $4^{\circ}$. inciso I, do Código Civil.

15 Não constitui objetivo de estudo a abordagem da maternidade, em razão das inúmeras implicações de temas como a maternidade por substituição.

16 Na esfera da maternidade, o Decreto $\mathrm{n}^{\circ} 18.542$ de 1928 disciplinou que resultava do termo de nascimento, o qual deveria sempre indicar a genitora, dando à declaração da pessoa idônea que foi registrar o parto a presunção de veracidade. A atual Lei de Registros Públicos (Lei $\mathrm{n}^{\circ} 6.015 / 73$ ) estabelece no artigo 52 a obrigação de fazer a declaração de nascimento, facultan do ao oficial, por motivo de dúvida. diligenciar sobre a verossimilhança da declaração. O Código Penal trata dos crimes contra o estado de filiação nos artigos 241-243, tipificando, por exemplo, o registro como seu do fillho de outrem. 
casamento posterior dos pais, ${ }^{17}$ ficando em tudo os filhos legitimados equiparados aos legítimos.

Esta equiparação só cabia aos filhos ditos naturais, enquanto os adulterinos, se a patre. dependiam de dissolução do casamento do pai, se a matre, aguardavam a dissolução do casamento da mãe e impugnação da paternidade por sentença judicial. No caso dos incestuosos, a legitimação somente ocorreria se o impedimento dos genitores de casarem-se ${ }^{19}$ fosse abolido ou afastado.

Assim sendo, a legitimação representava um importante caminho para a equiparação dos filhos, tanto assim que, segundo Pontes de $\mathrm{Mi}$ randa, ${ }^{20}$ "a legitimação de todos os filhos é a boa doutrina, e devemos recebê-la com aplausos porque se nos afigura mais eqüitativa, mais simples e mais acorde com as tendências igualitárias da civilização".

A legitimação significa, por conseguinte, o traço inicial da equiparação entre os filhos havidos dentro e fora do casamento, sendo a responsável direta pela atribuição do estado de filho legítimo ao natural.

Quanto ao reconhecimento, consistente num ato declaratório da filiação ilegítima, podia se operar espontaneamente em escritura pública, testamento, no próprio termo de nascimento, ou judicialmente, em sentença de ação de investigação de paternidade. O reconhecimento da filiação natural permitia que a verdade jurídica coincidisse com a biológica.

Para os adulterinos, o reconhecimento devia esperar a dissolução do vinculo matrimonial ou separação de fato há mais de 5 anos, se fosse da espécie a patre. No caso de adulterino a matre, o reconhecimento tinha que aguardar o transcurso do mesmo prazo qüinqüenal, e dependia de prévia declaração em sentença de impugnação da paternidade.

A investigação de paternidade é uma ação ordinária para declarar o estado de uma pessoa no aspecto da paternidade, tendo como pressupostos os casos elencados no artigo 363 do Código Civil, segundo a visão anterior à Constituição.

1. Artigo 353 do Código Civil.

18 Artigo 352 do Código Civil.

19 Artigo 183 do Código Civil.

20 Pontes de Miranda. Tratado de Direito de Familia. vol. III. Max I.imonad. São Paulo. 1947. p. 67.

R. Fac. Direito. Curitiba. a.27. n.27. 1992/93. p.141-202 
Da mesma forma que no reconhecimento voluntário, a investigação de paternidade do filho adulterino a patre ${ }^{21}$ condicionava-se à dissolução da sociedade conjugal ou separação de fato a mais de 5 anos, enquanto para o adulterino a matre, ${ }^{22}$ deveria ser precedida de uma ação declaratória de nulidade do registro ou, segundo a corrente mais liberal, de prova da separação de fato.

A investigação operada pelo filho incestuoso somente poderia encontrar um genitor, omitindo a menção do outro, sob pena de incorrer em nulidade.

O ônus da prova da paternidade cabe ao filho, a quem incumbe demonstrar a existência de relações da mãe com o suposto pai.

Da sentença que julga procedente a investigação diz-se que opera o reconhecimento judicial do filho ilegítimo.

Tanto o reconhecimento judicial, como o voluntário, foram alvos de mudanças com a Constituição, tornando-se importante meio de viabilizar a almejada igualdade de filhos.

No que se refere à posse do estado de filho, no sistema do Código, funciona como meio de prova da filiação legítima não guarnecida pelo título de nascimento, servindo de valiosa contribuição para a investigação, se aliada à prova de geração ou coabitação.

Em particular, a posse de estado é um fator de humanização do direito de filiação, em países que também adotam um sistema igualitário, sendo a análise dos efeitos constitucionais e sugestões, mais adiante realizadas.

\section{Evolução legislativa brasileira em matéria de filiação}

Dentro do ordenamento jurídico, a respeito da filiação, sucederam-se diversas leis ordinárias, bem como momentos de concessões e restrições de direitos.

21 Vide explicação supra sobre os filhos espúrios adulterinos no presente item.

22 Idem à anterior. 
$\mathrm{Na}$ tentativa de distinguir as várias etapas de normatização, pode-se dizer que o primeiro período começou com as Ordenações do Reino até a Lei $n^{\circ} 463$, de 1847, seguindo depois, o Código Civil, em 1916, o Decreto Lei $n^{\circ} 4.737$, de 1942 , a Lei $n^{\circ} 883$, de 1949, a Lei $n^{\circ} 6.515$, em 1977 e a Constituição Federal de 1988.

A princípio, cabe destacar que das Ordenações até o Código Civil decorreu um período de constante abrandamento das diferenciações entre os filhos, mas com a promulgação do Código Civil, que observou os ordenamentos alienígenas da época, especialmente o francês, operou-se um retrocesso em comparação com o direito pré-codificado.

O caminho para a reconquista da igualdade, todavia, foi árduo e duradouro, rompendo-se definitivamente com o sistema clássico somente com a Constituição Federal de 1988.

Quando do descobrimento do Brasil pelos portugueses, estavam vigentes no direito lusitano as Ordenações Afonsinas, vindo, depois, as Ordenações Manuelinas (1521) e finalmente as Ordenações Filipinas (1603), as quais vigoraram nas terras brasileiras até a promulgação de novas leis após a independência.

Para os filhos naturais, ${ }^{23}$ permitia-se o reconhecimento por escritura pública ou testamento, ${ }^{24}$ ouvidos previamente os herdeiros, dependendo de confirmação em Carta Régia.

Os meios de prova e defesa, na ação em que o filho natural investigava a paternidade, eram amplos.

Quanto aos efeitos do reconhecimento, sendo filho de plebeu, herdava na qualidade de herdeiro necessário, em igualdade com os filhos legítimos. No caso de filho com origem nobre, restringindo-se os efeitos do reconhecimento aos alimentos, não tinha direito sucessório, exceto quando não concorresse com herdeiros de outra classe. Na sucessão materna, fosse filho de nobre ou plebeu, tinha direito de herdar.

2.3 Concebidos na época como provenientes do ajuntamento de algum homem com alguma mulher solteira em que não houvesse entre eles parentesco ou impedimento.

24 Reconhecimento voluntário, portanto. permitindo àuele filho não abrangido pela presunção de paternidade a integraçào na entidade familiar.

R. Fac. Direito. Curitiba, a.27. n.27. 1992/93, p.141-202 
Os filhos espúrios, entendidos assim os nascidos de coito danado ou punivel, ${ }^{25}$ não herdavam do reconhecente, ${ }^{26}$ salvo se inexistissem herdeiros legítimos, porém tendo direito a alimentos se devidamente reconhecidos.

Com a Lei $\mathrm{n}^{\circ} 463$, de 1847 , a distinção entre filhos de nobres e plebeus findou, assentando-se que todos os filhos naturais poderiam suceder, se houvesse reconhecimento em escritura pública e estivessem concorrendo com os legítimos. Inexistindo contenda com outros herdeiros, a sucessão se operaria não só por escritura pública, como também por testamento.

Os espúrios permaneceram com o seu disciplinamento jurídico inalterado.

No cômputo geral, os filhos ilegítimos de plebeus sofreram restrições em seus direitos com a equiparação, enquanto os filhos de nobres foram beneficiados

No último momento antes do Código Civil, o Decreto $\mathrm{n}^{\circ} 181$, de 1890 ampliou as formas de reconhecimento voluntário do filho natural, para permitir a prova por confissão espontânea, reconhecimento em escritura pública, no ato de nascimento ou em outro documento autêntico, embora tenha vedado a investigação de paternidade para os filhos ilegítimos.

Desta evolução legislativa, denota-se uma posição discriminatória sobre a situação dos filhos havidos dentro e fora do casamento. Porém, se as dificuldades para a filiação ilegítima eram muitas, com a promulgação do Código Civil, simplesmente instituiu-se a proteção integral da família em prejuizo dos filhos, estabelecendo franca disparidade entre as classes de filhos.

No projeto de Código Civil elaborado por Clóvis Bevilácqua, não havia discriminação entre as espécies de filiação, seguindo a orientação igualitária. Todavia, por obra do deputado Andrade Figueira, dentre outros,

25 Ordenações Filipinas, Livro IV. Título 93. in Jussara Maria de Meirelles Fowler, "O principio da igualdade entre as diferentes categorias de filhos". Jurisprudencia Brasileira. Curitiba. Juruá. 1990(153).p. 20.

26. Regra que em 1828 acabou derrogada por uma lei que estabelecia a impossibilidade do filho espúrio suceder diretamente o reconhecente. exceto na hipótese de reconhecimento por testamento. 
a diferenciação foi introduzida no Código, para somente ser derrubada definitivamente com a promulgação da Constituição Federal de. 1988.

Originalmente, o Código Civil impedia o reconhecimento da filiação espúria (adulterina e incestuosa), conforme disposto no artigo 358, obstáculo para a perfilhação de caráter absoluto, quer se procedesse voluntariamente ou mediante provocação, ${ }^{27}$ considerando o ato como nulo no caso de inobservância da vedação fixada.

Destaque-se, que a iniciativa da ação para efeito de alimentos jamais poderia ser do filho incestuoso ou adulterino.

Apenas e tão-somente se demonstrada a existência de suposta paternidade, seja por sentença não provocada pelo filho para este fim, quer pela confissão ou declaração do pai, os filhos bastardos teriam direito a alimentos, nos moldes do artigo 405 do Código Civil.

No que se refere à posição do filho de desquitado, a doutrina e a jurisprudência tenderam ora para considerá-los como adulterinos, ora como naturais.

O entendimento que acabou prevalecendo, não obstante, foi o mais favorável ao filho, admitindo-se que o término do dever de coabitação cessa com o dever de fidelidade dos cônjuges e, conseqüentemente, não haveria adultério, embora o vínculo matrimonial fosse conservado. Destarte, os filhos originários deste relacionamento seriam tidos como naturais e não adulterinos.

Deste rápido apanhado de institutos, nota-se que o regime do Código Civil privilegiava a filiação legítima, aquela havida dentro do casamento e acobertada pela presunção de paternidade, permitindo aos filhos naturais a legitimação pelo casamento posterior dos pais, ou mesmo o reconhecimento, embora tivessem direitos sucessórios restritos à metade do que coubesse ao legítimo. ${ }^{28}$

Todavia, se para os filhos naturais ainda restou algum direito, quanto aos filhos adulterinos e incestuosos não se procedeu da mesma maneira,

27 Ação de investigação de paternidade.

28 Art. 1605. Para os ef eitos da sucessão, aos filhos legítimos se equiparam os legitimadıs. os naturais reconhecidos e os adotivos. $\S 1^{\circ}$. Havendo filho legitimo. ou legitimado, so à metade do que a este couber em herança terá direito o filho natural reconhecido na constância do casamento.

R. Fac. Direito. Curitiba, a.27. n.27. 1992/93. p.141-202 
deixando-os em completo abandono, salvo se provado, incidentalmente, o vínculo de paternidade para efeitos de alimentos.

O rigorismo do Código Civil somente começou a perder eficácia com a Constituição Federal de $1937,{ }^{29}$ a qual facilitou o reconhecimento dos filhos naturais, colocando-os em igualdade de condições com os filhos legítimos após a realização da perfilhação, principalmente quanto aos direitos hereditários.

A interpretação dos tribunais, receosa de inovações e acostumada com a discriminação do Código Civil, não tinha sido uníssona sobre os efeitos da proclamada igualdade, entendendo alguns, que não teria ocorrido revogação tácita do artigo $1605, \S 1^{\circ}$, do Código Civil.

O Decreto-Lei $n^{\circ} 4.737 / 42$ possibilitou que o filho adulterino não abrangido pela presunção ${ }^{30}$ fosse reconhecido voluntariamente ou demandasse a declaração de filiação, desde que posteriormente ao desquite do genitor casado. Não existindo previsão com relação a outras formas de dissolução da sociedade, a jurisprudência tratou de restringir ou estender a interpretação. ${ }^{31}$

A polêmica somente teve finalização com a Lei $n^{\circ} 883 / 49$, a qual permitiu que os filhos adulterinos a patre postulassem o reconhecimento após o desquite do genitor adúltero, além dos outros casos de dissolução posterior da sociedade conjugal, podendo-se operar no próprio termo de nasci mento, por escritura pública ou por testamento, dizendo respeito somente à filiação adulterina e deixando-se a filiação incestuosa no mesmo plano de desproporção jurídica que imperava no Código Civil.

29 Artigo 126 - Aos filhos naturais, facilitando-lhes o reconhecimento, a lei assegurará igualdade com os legítimos. extensivos àqueles os direitos e deveres que em relação a estes incumbem aos pais.

30) Adulterino a patre. ou seja. em que o genitor casado é o pai, sendo a mãe solteira.

31 Como exemplo de interpretação ampliativa: Investigação de Paternidade Reconhecimento de filho adulterino, no caso de ficar viúvo o pai - Aplicação do Decreto-Lei $n^{n}+737$ de 24 de setembro de 1942 - Aplicação extensiva por efeito de compreensão das leis que abrem exceção a regras gerais - Diferenciação da analogia Os motivos e a finalidade do Decreto-Lei $n^{\circ} 4737$ - Os filhos naturais e a legislação social - O viúvo, com ou sem descendència legitima pode reconhecer a prole adulterina, em face do que dispõe o Decreto-Lei $n^{o} 4737$ - O filho adulterino de pai viúvo pode pleitear o seu reconhecimento, com fundamento no citado Decreto-Lei (Martinho Garcez Neto, Questões de Familia. Rio de Janeiro. Forense, 1944. p. 95). 
No tocante ao filho adulterino a matre, a incidência da presunção de paternidade sobre o marido da mãe fez com que predominasse o entendimento de que o reconhecimento estaria sempre vinculado a uma prévia declaração em sentença de investigação de paternidade.

Outrossim, a Lei $n^{\circ} 883 / 49$ permitiu que o próprio filho ilegítimo demandasse contra o suposto pai em segredo de justiça, para efeito de prestação de alimentos, independente de prova pré-constituída e dissolução da sociedade conjugal, rompendo com a vedação de acionar o genitor.

A respeito dos direitos sucessórios, o filho adulterino reconhecido teria apenas a metade da herança do descendente ilegítimo, terminando com a lacuna proveniente do Decreto-Lei ${ }^{\circ} 4737 / 42$.

Sendo assim, tanto a Lei $n^{\circ} 883 / 49$ como o Decreto-Lei $n^{\circ} 4737 / 42$ foram diretamente beneficiar a filiação adulterina, afastando o artigo 358 do Código Civil para permitir o reconhecimento voluntário ou judicial depois de dissolvida a sociedade conjugal, firmando dois importantes marcos na caminhada para a conquista da igualdade.

A Lei $n^{\circ} 6.515 / 77$, também denominada de Lei do Divórcio, introduziu o parágrafo único no artigo $1^{\circ}$ da Lei $n^{\circ} 883 / 49$, passando a permitir que o reconhecimento do filho adulterino fosse realizado ainda na vigência do casamento, em testamento cerrado, bem como colocou o direito à herança em igualdade de condições, alterando, nesta parte, o artigo $2^{\circ}$ da referida Lei.

Assim sendo, teve início a permissão do reconhecimento voluntário ser operado na vigência da sociedade conjugal, embora em testamento cerrado.

Ademais, possibilitou que, depois de dissolvida a sociedade daquele condenado a prestar alimentos, o filho adulterino estivesse dispensado da propositura de investigatória, para obter o reconhecimento. Também se alterou a fixação das hipóteses legais de legitimação, retirando para o casamento putativo a antiga exigência de boa fé, ao menos unilateral, passando a entender que haveria legitimidade da filiação, mesmo que os dois pais tivessem conhecimento do impedimento para se casar.

Em 1984, a Lei ${ }^{\circ} 7.250$, atenta à realidade de muitas separações de fato, permitiu o reconhecimento do filho extra-matrimonial em ação de

R. Fac. Direito. Curitiba, a.27, n.27. 1992/93. p.141-202 
investigação, desde que a separação dos cônjuges tivesse mais de 5 anos contínuos.

A separação de fato com mais de 5 anos, desta forma, passa a permitir que a presunção de paternidade seja derrubada para o filho adulterino postular o seu reconhecimento, traduzindo a Lei $n^{\circ} 7.250 / 84$ o último marco rejuvenescedor do sistema clássico de filiação que o Código Civil adotou.

A Constituição Federal de 1988 alterou a visão tradicional e colocou os filhos em plano de completa igualdade, estabelecendo no seu artigo 227 , $\S 6^{\circ}$, que os filhos, havidos ou não da relação do casamento, ou por adoção, terão os mesmos direitos e qualificações, proibidas quaisquer designações discriminatórias.

A eqüidade aplicada à filiação, entretanto, decorre igualmente da necessidade que a ampliação das formas de família trouxe para a disciplina do vínculo de filiação, uma vez que a admissão de outras formas de união familiar não poderia deixar os filhos havidos destas uniões desguarnecidos da proteção do ordenamento.

Seguindo a orientação constitucional, a Lei $n^{\circ} 7.841 / 89$ revogou o artigo 358 do Código Civil, o qual até então impedia os filhos incestuosos e adulterinos de demandarem o reconhecimento, iniciando nova fase de surgimento de leis ordinárias, desta feita embasadas em motivação totalmente diversa das anteriores, as quais deverão ser voltadas para o prazer e satisfação do componente da família, deixando de haver submissão da vínculação dos membros da família, conforme o interesse de manutenção do grupo.

O Estatuto da Criança e do Adolescente, Lei $n^{\circ} 8.069 / 90$, em seus artigos 26 e 27 , eliminou a impossibilidade de reconhecimento que recaía sobre o filho havido fora do casamento, permitindo que seja realizado por meio de termo de nascimento, testamento, escritura pública ou outro documento público, independentemente da origem da filiação.

Finalmente, como a mais nova norma acerca da Filiação, a Lei $n^{\circ}$ $8.560 / 92$ teve o franco propósito de favorecer a prole não matrimonial: ${ }^{32}$ instituiu a possibilidade de reconhecimento por instrumento particular ou

32 João Baptista Villela, "Reconhecimento da paternidade entre o pós-moderno e o arcaico: primeiras observações sobre a Lei $\mathrm{n}^{\circ} 8.560 / 92 "$, Repertório IOB de Jurisprudência (3): 71-76, $2^{\mathrm{a}}$ quinzena, fevereiro de 1993. 
público, desde que arquivado, além da forma por testamento, se manifestado incidental mente; admitiu as hipóteses de confissão expressa e direta perante o juiz; estabeleceu a averiguação oficiosa de paternidade; conferiu legitimidade ao Ministério Público para propor ação de investigação de paternidade e concedeu direito de silêncio sobre a origem da filiação, no assento de nascimento, dentre outras mudanças.

Agrupando todas as leis mencionadas, para sistematizá-las, permitese inferir, que no Brasil, a filiação passou por três etapas distintas: direito pré- codificado; Código Civil e Constituição Federal de 1988.

O estudo adequado da igualdade deve ser precedido, ainda, de uma última análise sobre os direitos que envolviam os filhos legitimos, legitimados e reconhecidos no sistema imediatamente anterior à Constituição Federal, da mesma forma que as sugestões doutrinárias no decorrer deste período também merecem destaque, para que com esta retaguarda seja possivel traçar as conseqüências sobre o ordenamento jurídico da filiação.

\section{Direitos dos filhos legítimos, legitimados e reconhecidos antes da constituição}

No rol de direitos concedidos aos filhos legítimos pelo sistema originário do Código Civil, como decorrência especial do favor legitimitatis, pode-se mencionar a criação de um estado, o qual consiste na posição que a pessoa tem no meio social, a sua condição valorizada pela sociedade, contendo um complexo de qualidades particulares.

A partir dessa noção de favorecimento, concede-se ao filho legítimo direitos pessoais e patrimoniais.

Na seara pessoal, depara-se primeiro com o direito ao nome, permitindo a representação e documentação, uma vez que designa a pessoa, identificando-a perante os demais componentes da sociedade.

$\mathrm{O}$ nome divide-se em prenome e patronímico, aquele o designativo individual, este a atribuição da família usada pelo descendente, segundo uma transmissão hereditária. Aliás, o patronímico é fator de extrema importância na vida social, pois representa a origem familiar do filho, o que, muitas vezes, pode decidir o seu destino.

R. Fac. Direito. Curitiba. a.27. n.27. 1992/93. p.141-202 
O parentesco surge imediatamente com a determinação do vínculo de filiação, gerando a possibilidade do filho receber afeto e auxílio pecuniário de todos os colaterais, de grau próximo ou remoto, desde que haja alguma ligação social dos familiares com seus parentes.

O pátrio-poder, por outro lado, tem a função de atribuir direitos e deveres para ambos os pólos da relação jurídica de filiação, isto é, para o genitor e filho, sendo construído com a função precípua de proteger o filho e assegurar o desenvolvimento da sua personalidade.

A respeito, cabe citar o escólio de Mário Aguiar Moura: ${ }^{33}$

"Nunca é demais ressaltar que o mais amplo e constante relacionamento pais-filhos é obra do sentimento ético das pessoas em face da filiação. Os cuidados, desvelo, carinho, orientação, previsão e proteção, enfim, toda a silenciosa e constante tarefa desenvolvida pela paternidade em sentido lato, em sua maior parte decorre da constelação emocional fornecida pelo instinto de paternidade e maternidade."

Sendo assim, o pátrio-poder é responsável pela construção do filho em sentido figurado, encerrando os deveres de criação, educação, guarda e vigilância, consentimento para casar, nomeação de tutor, representação e vindicação do filho. Aliás, esta última circunstância se traduz, na moderna processualística vigorante entre nós a partir de 1973, na ação cautelar de busca e apreensão, quando cabível.

$\mathrm{Na}$ área dos efeitos patrimoniais, os filhos legítimos possuem direitos sucessórios, incluindo-se na classe dos herdeiros necessários, de tal forma que a parte deles no quinhão hereditário é garantida, tendo preferência por serem chamados à herança antes de outros sucessores.

Os alimentos devem ser naturalmente prestados, ficando para o genitor a administração e usufruto dos bens do filho legítimo enquanto menor.

Esta gama de proteções e direitos envoltos no estado de filho sofre um alargamento na sua aplicação com a Constituição de 1988, deixando-se para os capítulos seguintes o estudo das suas implicações.

33 Mário Aguiar Moura, Tratado prático da filiação, $3^{\circ}$ vol., Rio de Janeiro, Aide, 1984, p. 781 . 
Quanto aos filhos legitimados, segundo a própria disciplina do Código Civil, não existia diferença em termos de direitos perante os filhos legítimos, apenas que a partir da legitimação por casamento posterior, os filhos teriam a mesma proteção atribuída aos portadores do favor legitimitatis, deixando de alcançar retroativamente o nascimento.

Em relação aos filhos reconhecidos, os efeitos da perfilhação dizem respeito à atribuição de estado de filho, tendo estes a faculdade de adotar o patronímico do pai, o qual revela, neste particular, o vínculo de parentesco.

As relações de parentesco, outrossim, estabelecem a reintegração do filho reconhecido na família, colocando-o em posição de igualdade, inclusive com a aplicação do pátrio-poder.

A restrição, no entanto, encontrava-se no artigo 359 do Código Civil, impossibilitando o ingresso do filho reconhecido no lar conjugal, sem o consentimento da esposa, a fim de evitar, com isso, a desagregação da sociedade conjugal. Contudo, a manutenção e sustento do filho em outro lar deve se dar às custas do cônjuge reconhecente, em decorrência da conservação dos deveres do pátrio-poder sobre este.

Os alimentos cabem a partir do reconhecimento e a atribuição de relação sucessória, primeiro, pela metade se concorresse com filhos legítimos e legitimados (artigo 1605, $\$ 1^{\circ}$, do Código Civil) e depois, em igualdade com os filhos legítimos (artigo 51, II, da Lei do Divórcio), conforme evolução legislativa já comentada.

A previsão do artigo $3^{\circ}$, da Lei $n^{\circ} 883 / 49$, aliás, atribuiu outra discriminação em matéria sucessória entre os filhos legítimos e reconhecidos, tendo como fundamento a garantia de sobrevivência do cônjuge casado sob o regime de separação de bens, argumentando-se, também, com a ausência de vínculo de natureza sentimental entre o sobrevivente e o filho reconhecido, de forma que estabeleceu direito de herdar pela metade ao filho reconhecido, se concorresse exclusivamente à herança.

Ressalte-se que o efeito sucessório é o mais importante dentre os possiveis para o reconhecimento, pois centraliza em muitos casos os interesses que envolvem a pretensão do reconhecimento voluntário ou judicial.

R. Fac. Direito. Curitiba. a.27. n.27. 1992/93. p.141-202 


\section{Algumas propostas doutrinárias que antecederam a Constituição Federal de 1988}

A filiação e seu tratamento jurídico sempre foram alvo de grande preocupação dos doutrinadores; uns, buscando conferir privilégios aos filhos, somente por serem fruto de uma relação conjugal matrimonializada; outros, almejando obter a equiparação entre as diversas espécies de filiação, independente do relacionamento legalizado dos pais.

Nesta etapa, serão expostas algumas tendências manifestadas em favor da igualdade de filiação, que antecederam à Constituição Federal de 1988 , tratando-se de trabalhos e argumentos oriundos de um período em que a discriminação estava disseminada no direito brasileiro, isto sem deixar de dar oportunidade ao contraditório da visão conservadora.

Sem dúvida alguma, o precursor das idéias igualitárias na seara da filiação, foi Enrico Cimbali, ${ }^{34}$ autor citado em todas as obras jurídicas pertinentes, encarregando-se de uma análise aprofundada sobre os argumentos contrários e favoráveis à diferenciação entre os filhos.

A obra de Cimbali foi escrita no final do século XIX, aproximadamente em 1890, provocando grande interesse pela árdua campanha anti-discriminatória que desenvolveu.

Identificou ele que a causa jurídica da severidade contra os filhos espúrios estava em representarem fatos contrários à ordem das famílias e ofensivas à moralidade pública, verdadeira "expressão de fato vituperável". O nascimento de filho espúrio era visto como calamidade pública, justificando, esta repulsa, a negativa imposta ao direito de postular em juízo a investigação.

Na verdade, os filhos espúrios revelavam concretamente as torpezas de seus genitores.

Ousou Cimbali observar que a responsabilidade pelo fato repugnante caía sobre a vítima, propugnando o tratamento racional dos filhos havidos fora do casamento - expressão originalmente utilizada - em nome da natureza, tendo alguma mitigação decorrente da necessidade de coexistência com os direitos sagrados da sociedade.

34 Enrico Cimbali, A nova phase do direito civil em sua relações econômicas e sociais. Tradução Adherbal de Carvalho, Porto e Rio de Janeiro, Livraria Clássica e Chardron, 1900 , p. 195-229. 
Propôs ele, que fosse princípio fundamental a obrigação dos pais reconhecer os filhos espúrios, alimentar, educar e garantir-lhes a sucessão, em homenagem ao dever de suportar as conseqüências do próprio fato, bem como porque, sendo a causa da vida, deveriam fornecer condições para a própria vida.

Em demonstração do pensamento que envolvia o momento de elaboração do seu trabalho, Cimbali relatou, todavia, que deveria ser evitado que os direitos dos filhos havidos fora do casamento fossem perfeitamente iguais aos que gozam os legitimos, para desta forma servir de garantia do direito que compete à sociedade e, ao mesmo tempo, garantir o direito que compete ao indivíduo.

Como forma de solução deste antagonismo de interesses, de um lado o indivíduo e de outro a sociedade juntamente com a família, propôs a conciliação com o direito dos filhos havidos fora do casamento, de usarem o nome, receberem alimentos e educação dos pais de procriação, não gozando dos benefícios do pátrio-poder do mesmo modo que os filhos legítimos e nem concorrendo à sucessão, porque a cota necessária não deveria ser igualada à destes.

Contrário à visão de Cimbali, Pontes de Miranda, ${ }^{35}$ em obra de 1947 , critica-o opondo à sua teoria o fato de que a legitimação dos adulterinos tiraria dos filhos legítimos seus direitos sucessórios que a lei devia resguardar, do mesmo modo que a legitimação do filho incestuoso daria caráter jurídico para a relação criminosa.

No entender de Pontes, o equívoco de Cimbali consistiu em ver a questão sob o ponto de vista da eqüidade, de forma que no caso dos incestuosos não poderia haver casamento válido para os genitores, enquanto a igualdade concedida aos filhos adulterinos estaria favorecendo e incentivando a união de pessoas por simples concubinato.

Dentre os notáveis autores que defenderam a igualdade de filiação, pode-se incluir J. M. de Carvalho Santos, ${ }^{36}$ o qual criticou o sistema do Código Civil, dizendo que não havia racionalidade em procurar castigar o

35 Pontes de Miranda, Tratado..., op. cit., p. 67.

36 J. M. de Carvalho Santos, Código civil brasileiro interpretado, vol. V. São Paulo. Freitas Bastos, 1963, p. 437-438.

R. Fac. Direito. Curitiba, a.27. n.27, 1992/93. p.141-202 
fruto das uniões extra-matrimoniais para valorizar o casamento e solidificar os alicerces da família.

Considerava ele injusto que o filho fosse punido quando a responsabilidade seria dos pais, argumentando ser irritante o propósito legal de querer que o filho não tenha pai, fato contrário à natureza.

Ademais, abriu os caminhos para igualdade ao criticar como contraproducente o sistema do Código Civil, ao deixar de punir os culpados, colocando-os em posição mais favorável, até mesmo privilegiada, desde que os isentava de algumas tantas obrigações e de outros deveres que somente os pais casados cumpriam.

Por fim, considerou Carvalho Santos que o Código estimulava o adultério, posicionando o casamento em inferioridade, pois os pais legalmente casados têm a obrigação decorrente do pátrio-poder para com os filhos, enquanto nem considera pais os que se serviram do adultério ou incesto.

Em trabalho realizado no ano de 1977, Antônio Chaves ${ }^{37}$ informava que nada justificava a responsabilidade dos filhos pelas atitudes dos pais, além do mais quando o destino e a felicidade dos espúrios ficaria dependendo da boa fé e sentido de humanidade dos progenitores.

Segundo ele, a barreira de preconceitos sociais em que tudo quanto fosse concedido ao filho ilegítimo redundaria em prejuízo do patrimônio moral da família legalmente constituída, quando não incentivo às uniões livres, deveria ser transposta.

Entre as grandes propostas que surgiram neste período negro da história da filiação, Orlando Gomes ${ }^{38}$ defendeu a abolição da ilegitimidade com fundamento de que todo filho era legítimo para o seu pai. Pretendeu, ainda, a retirada dos pressupostos de admissibilidade para a ação de investigação de paternidade, conferindo-se liberdade de postulação em juízo.

$\mathrm{Na}$ esfera dos direitos dos filhos havidos fora do casamento, propôs que estes recebessem o sobrenome dos legítimos se a atribuição fosse simultânea ao nascimento, porém, na hipótese de ulterior modificação do

37 Antonio Chaves, Filiação Espúrio. in Enciclopédia Saraiva do Direito, Verbete Filiação Espúria, Vol. 37, São Paulo, Saraiva, 1977, p. 258-275.

Orlando Gomes, O novo direito de família, Porto Alegre, Fabris, 1984, p. 75. 
estado, a sua realização dependeria do consenso do filho ao completar dezoito anos de idade.

Outrossim, o jurista baiano propugnou que os filhos adulterinos tivessem direitos ilimitados de reconhecimento, seja voluntário ou judicial, concedendo limitações ao reconhecimento, apenas se fundamentadas na incompatibilidade com os direitos da família legítima.

De acordo com este entendimento, a proibição repousa na proteção do cônjuge e não na violação do dever de fidelidade.

Para os incestuosos, seria possível reconhecê-los onde a filiação resultasse juridicamente do nascimento, ou seja, no ordenamento que extinguisse a categoria, assim como nos países que permitissem o reconhecimento por apenas um dos genitores.

Termina sua argumentação propondo uma política legislativa destinada à proteção do menor, e não do filho.

No sentido restritivo da igualdade de filiação, João Baptista Villela, ${ }^{39}$ em trabalho que antecedeu a Constituição, pretendeu aplicar a construção jurídica alemã ao sistema nacional, uma vez que, segundo ele, os dois seriam inspirados na mesma visão cultural básica.

Em consonância com esta premissa, defendeu que para haver igualdade de filiação, somente com a igualdade de qualificação já seria possível, não devendo existir uma igualdade de direitos de modo absoluto, chegando à conclusão de que a solução estaria em usar expressões neutras, que não vinculem além do inevitável juízo de valor quanto à natureza da filiação.

Este rápido apanhado doutrinário revela uma linha de pensamento de extrema coincidência entre os autores que mais abordaram a igualdade de filiação: a proteção da família legítima e seus filhos e, sobretudo, a noção de que a família existia para o indivíduo, e não o contrário.

A superação de tais fundamentos produz uma ampliação de direitos dos filhos ilegítimos, embora não os equipare totalmente aos legítimos, sempre permanecendo algum resquício de diferenciação, pois a completa igualdade entre eles representaria a diminuição dos poderes da filiação

39 João Baptista Villela. "Casamento e família na futura Constituição brasileira: a contribuição alemã". Revista de Informação Legislativa. 1987(96). p. 291-302.

R. Fac. Direito. Curitiba. a.27. 1.27. 1992/93. p.141-202 
legítima, praticamente extinguindo com o favor legitimitatis, consentâneo com a realidade legislativa da época.

Excetuam-se desta conclusão Carvalho Santos e Antônio Chaves, ambos doutrinadores com importantes idéias de igualdade que não seguem a regra de ainda diferenciar os filhos, defendendo a atribuição da eqüidade à filiação por ser a melhor maneira de responder aos argumentos por eles utilizados, especialmente a equivocada inversão de valores e o beneficiamento dos pais adúlteros, por exemplo, com a não atribuição de paternidade.

Independente do grau de igualdade almejada pelos doutrinadores referidos, todos contribuíram para o rompimento do sistema de filiação concebido pelo Código Civil, de modo que os entendimentos manifestados merecem louvor pela sua natureza desbravadora.

\section{Da percepção de família contemporânea e suas regras constitucionais}

Considerando que a abordagem da filiação costumeiramente ocorre por meio da "janela" da família, a presente etapa procura introduzir uma nova concepção e os respectivos dispositivos constitucionais, cessando com o equivocado ponto de vista clássico sobre o vínculo de filiação.

A tradicional regulamentação concebia a família com ampla ficção no amor entre os cônjuges de caráter perpétuo, composta com a paternidade marital e profundamente contrária ao reconhecimento do vínculo de filiação do filho havido extra-matrimônio.

A disciplina era severa sobre o comportamento sexual e o desenvolvimento do mesmo, caracterizando uma herança de caráter cultural das antigas famílias, o que levava à condenação da ilegitimidade.

Seguindo esta conjectura conservadora, a filiação havida fora do casamento representava o rompimento com a união de sexo e procriação sob a guarida do matrimônio, modelo tido como ideal, propiciando a aplicação de uma fiç̧ão negativa que privava o filho ilegítimo de adquirir valores essenciais incorporados no estado de filho legítimo, taxando-o com denominação pejorativa que o acompanharia durante toda a sua vida, seja 
materialmente, com a repugnância social, ou no inconsciente de suas atividades.

Operou a Constituição, entretanto, uma alteração desta visão tradicional e discriminatória, ampliando-se as formas de família protegidas pelo direito e, via de conseqüência, eliminando a distinção que recaía sobre as espécies de filiação, pois os filhos oriundos das novas famílias guarnecidas pelo direito não poderiam ser diferenciados, enquanto componentes do grupo familiar admitido juridicamente, dos filhos originados na família constituída pelo casamento.

A Constituição de 1988, desta sorte, produziu a diáspora com o sistema clássico que já estava gradativamente sendo alvejado por leis ampliativas de direitos da filiação ilegítima, senão pelos próprios julgadores, ao constatarem que havia uma crise diante da incapacidade e injustiça da lei, na solução de questões envolvendo a filiação, conformando a apreensão do fenômeno jurídico da família pelo seu ângulo social.

A família passa a ter importância como comunhão de vida voltada para a consagração dos aspectos individuais, significando que as pessoas não estão mais dirigidas para a proteção do grupo e casamento, mas a família e o matrimônio estão voltados para a realização dos interesses dos seus componentes, aprimorando o aspecto social e almejando a felicidade. ${ }^{40}$

A percepção unitária da idéia de família e pluralitária com relação aos filhos inverteu-se, passando a entender como entidade familiar não só o casamento, como também a união estável e a comunidade entre um dos ascendentes e os descendentes. Os filhos, por sua vez, tiveram instituído o princípio de igualdade, que transformou as diversas categorias antigamente existentes, para aplicar um estatuto único.

Aliás, no que diz respeito à comunidade entre um dos ascendentes e os descendentes, a incorporação de tal realidade demonstra o recepcionamento da família pós-nuclear, não se restringindo mais à família nuclear constituída pelo pai, mãe e filho.

Quanto à união estável, ela dispõe atualmente de proteção estatal, inobstante o facilitamento de conversão da união estável em casamento, o que insinua a manutenção de um benefício para quem contrair núpcias.

40 Andrée Michel: Cf. Luiz Edson Fachin. Estabelecimento da filiação e paternidade presumida. Porto Alegre. Fabris. 1992. p. 15.

R. Fac. Direito. Curitiba. a.27. n.27. 1992/93. p.141-202 
O Direito Civil brasileiro passou, portanto, de uma única família, a matrimonializada, a ter três formas de entidade familiar, todas amparadas pelo dever de proteção do Estado.

A paternidade foi desvencilhada do estigma protetor para the ser atribuído o princípio da paternidade responsável, instituindo o dever jurídico dos pais para com os filhos, inclusive com a responsabilização pelos danos causados ao filho se descumprida a realização do seu dever.

Tanto o filho como o pai também foram incumbidos do dever mútuo de ajuda e amparo.

Considerou a Constituição que a educação é dever do Estado e da família (artigo 205), concedeu direito de lazer e descanso (artigos $6^{\circ}$ e $7^{\circ}$ ), direito de profissionalização (artigo $5^{\circ}$, XIII), direito à cultura (artigo 215), direito à dignidade (artigo $1^{\circ}$, inciso III), direito ao respeito (artigo $5^{\circ}$, III, $\mathrm{X}$ e LVIII), direito à liberdade (artigo $5^{\circ}$, incisos IV, VI e XV), direito de convivência e proibição de discriminação (artigo $3^{\circ}$, inciso III e IV: artigo $5^{\circ}$, caput e inciso XLI; artigo $227 . \S 6^{\circ}$ ), proibição de exploração de incapazes (artigo $227, \S 4^{\circ}$ ), direito à herança (artigo $\left.5^{\circ}, \mathrm{XXX}\right) .^{41}$

A ampliação constitucional protetiva em matéria de família, em especial devido aos princípios de dignidade humana e paternidade responsável, culminou com a equiparação de direitos e ausência de discriminação para os filhos, conforme redação do artigo $227, \S 6^{\circ}$.

\section{Princípio da igualdade}

A concepção de igualdade dos homens considera que todos são seres humanos dotados com a inteligência indispensável para a vida de relação, o que indubitavelmente acontece.

As tendências de aplicação da igualdade são oriundas do aprimoramento psíquico e cultural do ser humano como ente social, revelando a igualdade já existente no mundo fático.

41 Iosé luiz Gavião de Almeida. "() novo estatuto da filiação". in () direito de familia na nova constituição. Organização Carlos Alberto Bittar. São Paulo. Saraiva. 1992. p. $153-186$. 
A ignorância deste dado concreto, todavia, produz conseqüências psíquicas para o ser discriminado, podendo-se citar a tendência dos efeitos da discriminação permanecerem incutidas nas atitudes da pessoa objeto de diferenciação, inibindo-a de encontrar a força necessária para impedir os desvios de ordem social e psicológica, o que ocasiona o seu desajustamento social.

A noção jurídica de igualdade, caso seja dirigida à área formal, consiste apenas na igualdade perante a lei; contudo, visto este conceito na sua dimensão material, designa a equiparação de todos perante os bens da vida.

A igualdade aspirada pelas constituições brasileiras anteriores à atual, limitando-se ao plano formal-abstrato, mencionava o princípio de equiparação de situações perante a lei. Aplicado ao nosso tema, ele significaria que todos os filhos legítimos mereciam idêntico tratamento do aplicador da lei, mesmo que na prática permanecesse a discriminação dos filhos ilegítimos.

A igualdade perante a lei, todavia, não é somente nivelar determinada categoria de pessoas diante da norma jurídica. A própria lei, enquanto regulamentadora de fatos, deve ser editada em conformidade com a isonomia, coibindo-se a utilização de institutos como o favor do filho legítimo.

Logo, não apenas o aplicador da lei deve usufruir do princípio da igualdade, como determina a Lei de Introdução ao Código Civil, ${ }^{42}$ mas principalmente o legislador, ao desenvolver seu trabalho, deve equiparar diferenciações injustificáveis.

A lei não pode ser fonte de discriminações, evitando conferir privilégios e perseguições com fundamento em errônea apreensão da realidade, tarefa a ser realizada com utilização de tratamento eqüitativo dos cidadãos e, porque não dizer, dos próprios filhos.

Encontra-se, desta maneira, o meio de aplicar uma igualdade no plano formal-objetivo, definindo-se em quais casos será imperativa a equiparação, e quando terá validade o estabelecimento de desigualdades.

42 Art. $4^{\circ}-" \ldots$ principios gerais de direito".

R. Fac. Direito. Curitiba, a.27, n.27. 1992/93. p.141-202 
A dificuldade está, não obstante, no fato de que o legislador naturalmente discrimina situações e classifica pessoas e coisas à luz dos mais diversificados critérios, ${ }^{43}$ tanto assim que a função da norma, por sua própria origem, encerra alguns fatos sociais e deixa outros ao relento, por apresentarem menor interesse, o que revela uma natureza discriminatória.

A solução para o impasse, portanto, é valorar situações que justificam diferenciação ao se levar em conta determinado elemento diferencial, porém, sem fixar desigualdades que coloquem em risco a dignidade da pessoa humana ou a prive de direitos fundamentais.

A igualdade material, por assim dizer, deve se encarregar de reduzir as desigualdades sociais, assegurando a conquista eqüitativa dos bens da vida.

Ressalte-se que a igualdade material deve ser verdadeira e efetiva, assentando-se como meio de coibir favoritismos e perseguições.

A soma da igualdade material com a formal leva ao tratamento desigual de situações desiguais na inversa proporção da desigualdade, beneficiando aquele que concretamente era prejudicado.

Mesmo já definido o sentido de igualdade, cabe encontrar critérios seguros para fixar os casos de lesão a este princípio fundamental.

Na peculiar obra acerca do princípio da igualdade no âmbito jurídico, Celso Antônio Bandeira de Mello fornece algumas diretrizes para a identificação do desrespeito à isonomia, abaixo transcritas: ${ }^{44}$

"a) Quanto ao elemento tomado como fator de desigualação:

b) Quanto à correlação lógica abstrata existente entre o fator erigido em critério de discrimine a disparidade estabelecida no tratamento jurídico diversificado:

c) Quanto à consonância da correlação lógica com os interesses absorvidos no sistema constitucional."

Complementando seus critérios, esse autor determina que para não haver discriminação, são indispensáveis os três elementos, sob pena de que 1.5 Luís Roherto Barroso. "Igualdade peraute a lei". Revista de I ireito Público. São Paulo. $1986(78) \cdot$ p. 68.

4 Celso Antônio Bandeira de Mello. O contéudo juridico do principio da igualdade. São Paulo. Ed. Revista dos Tribunais. 1978, p. 27 
a ausência de apenas um deles já demonstre a ofensa ao princípio igualitário.

No que diz respeito ao elemento tomado como fator de discriminação, relata o doutrinador que a lei não pode adotar critério singularizador de uma pessoa para considerá-la individualmente, como também insiste que o fator de diferenciação há de estar na própria pessoa e não em elementos ela exteriores.

A correlação lógica refere-se, segundo ele, à adequação racional entre o fator erigido em critério de discrimine a diferenciação legal decidida em função dele.

Quanto à última diretriz, consonância da correlação com os interesses constitucionais, trata-se da necessidade do fundamento lógico da desequiparação estar na mesma linha da Constituição.

Somente se toleram desigualdades naturais, especialmente pela diferença de idade, saúde, força e desenvolvimento psicológico.

No âmbito familiar, a primeira e decisiva aplicação desta igualdade se encontra na equiparação entre o marido e esposa, ${ }^{45}$ ambos tendo os mesmos direitos e obrigações.

O emprego da eqüidade formal pura induziria a mulher ao prejuízo, uma vez que, mesmo com o grau de desenvolvimento da sociedade urbana, ainda se conservam os moldes machistas em muitas regiões interioranas, senão mesmo nos grandes centros. A onda diferenciadora iniciada na antigüidade, ainda produz efeitos, contudo, está lentamente perdendo sua energia e terminando suas conseqüências.

$\mathrm{Na}$ área de filiação o panorama é ainda pior, haja vista que os interesses envolvidos sempre foram intensos, inclusive com o beneficiamento expresso dos filhos legítimos, o que torna difícil galgar o sistema tradicional.

\section{Da igualdade na filiação}

O princípio da igualdade de filiação, na forma colocada pela Constituição, revela um fundamento humanitário, verdadeiro remédio contra a 45 Artigo 226, $\S 5^{\circ}$, da Constituição Federal.

R. Fac. Direito, Curitiba, a.27, n.27. 1992/93. p.141-202 
falsidade de um sistema jurídico oposto à natureza, passando-se da omissão para a interferência ativa na defesa da infância.

A Constituição cessou com a discriminação antes havida, aplicando a visão unitária da filiação e igualdade de tratamento com respeito à procriação, no sentido de verdade biológica, inclusive abrindo indiretamente passagem para a proteção da filiação sócio-afetiva, atendendo concomitantemente para a necessidade de assegurar a estabilidade emocional do filho.

A aplicação do princípio de eqüidade na filiação deve considerar que, como bem disse o professor Francisco Muniz, ${ }^{46}$ os princípios constitucionais do direito de família têm eficácia jurídica direta e são, portanto, normas vinculativas.

Não há como se pensar, portanto, em postergar a aplicação da igualdade na filiação, somente porque decorre ainda um período de lacuna em determinados campos.

Dentre as opiniões que defendem a aplicação imediata da igualdade de filiação, encontra-se a professora Jussara Maria de Meirelles Fowler. ${ }^{47}$

Tal entendimento, por sinal, tem o apoio de José Afonso da Silva, ${ }^{48}$ alegando ele que os princípios gerais informadores da ordem jurídica nacional, como o princípio da isonomia, são de eficácia plena e aplicabilidade imediata, auto-aplicáveis na terminologia norte-americana.

Neste ponto, a tese defendida pela desembargadora Áurea Pimentel Pereira, ${ }^{49}$ ao relatar que a Constituição teria pretendido somente evitar a publicidade das qualificações, admitindo que as designações discriminatórias devem permanecer e, além disso, que as regras sobre o reconhecimento e principalmente a proibição de reconhecimento do filho incestuoso ainda permanecem, fundamentadas no fato de representarem

46 Francisco José Ferreira Muniz, O Direito de Família na solução dos litígios, Conferência proferida no XII Congresso Brasileiro de Magistrados, Curitiba, Março-1992, p. 5.

47 Jussara Maria de Meirelles Fowler, "O principio...", op. cit., p. 19 e ss.

48 José Afonso da Silva, Aplicabilidade das normas constitucionais, São Paulo, Ed. Revista dos Tribunais. 1982, p. 108.

49 Áurea Pimentel Pereira, A nova Constituição e o Direito de Família. Rio de Janeiro, Renovar. 1989. p. 137-139. 
estas diferenças a pedra basilar do Direito de Família, não pode vingar em hipótese alguma.

Atenta para a realidade, a jurisprudência responde à norma igualitária com a atribuição de imediata aplicabilidade. ${ }^{50}$

Sendo assim, a norma constitucional não deixa dúvidas, estabelecendo a igualdade de direito e qualificações com aplicação imediata, independente de momentânea lacuna, descabendo pensamento contrário.

Em termos de direito comparado, ${ }^{51}$ cabe noticiar que a Constituição de Cuba de 1947 já abolia toda qualificação discriminatória para a natureza da filiação; na Suíça, com as revisões de 1972 e 1976, o princípio da unidade da filiação passou a ser aplicado, renunciando-se a distinção entre as espécies de filhos; na Áustria, no ano de 1977, uma lei aproximou a situação do filho natural o quanto possivel; na Bélgica, a doutrina e jurisprudência introduziram a equiparação total dos filhos; na França, o Código Civil 1972 previu o princípio da igualdade entre todos os tipos de filhos; em Portugal, a proibição de discriminação foi instituida com a reforma do Código Civil em 1977.

Ultrapassados possíveis desvios inadequados para o sistema vigente, bem como verificados os parâmetros de direito comparado, deve-se lembrar que não somente a pessoa do próprio filho sofria com a arbitrária discriminação legal, mas também a sociedade ao ter que acolher este filho tido como indigitado no meio de vida, ainda mais quando isto podia reverter em comportamento avesso ao convívio harmonioso.

s0 Filiação - Menor Reconhecido fora do Casamento - Ação anulatória proposta pela Esposa Legítima do Pai - Pretensão daquele em continuar usando o nome do ('enitor - Conflito aparente de Normas (lei 6.015/73. art. 60 e lei 6.515/77. art. 51) - Reconhecimento válido - Aplicação, como jus superveniens. do art. 227. $\S 6^{\circ}$. da Cff/88 - Preceito constitucional de aplicação Imediata. Não subsistem as restrições ao reconhecimento dos fillhos havidos fora do casamento, que eram consagrados no direito anterior, diante do preceito contido do art. $226, \S 6^{\circ}$, da Constituição Federal de 1988. Cuida-se de norma constitucional de aplicação imediata, que atingiria até as situações já consolidadas, quanto mais aquelas ainda não definitivamente julgadas (Tribunal de Justiça de São Paulo, $8^{\mathrm{a}}$ Câmara Cível, Embargos Infringentes 88.953-1, julgado em 14.12.1988, Rel. Des. Villa Costa. Apud in Jurisprudência Brasileira, Juruá, Curitiba, 1989 (150): 328-330 ).

51 Luiz Edson Fachin. Estabelecimento..., op. cit..p. 73 e ss.: Sérgio Gischkow Pereira. "Tendências modernas do Direito de Família". Revista da Faculdade de Direito da universidade Federal de Uberlândia, 1989(18). p. 295-323: José da Costa Pimenta. Filiação, Coimbra, Coimbra Ed., 1986. p. 16. 
No nosso ver, o equívoco de considerar apenas a existência do vínculo de filiação, quando houvesse legítima união entre os pais peca por fugir da pessoa do filho para encontrar nos pais o fator de discriminação.

A lição de Celso Antônio Bandeira de Mello está correta, a partir do momento em que o elemento aplicado como fator de discriminação é exterior à pessoa do filho, de tal sorte, que para conceder privilégios aos filhos legítimos, empregava-se a forma de união dos pais como determinante da existência do vínculo de filiação.

A antiga discriminação legal do sistema clássico equivoca-se ao utilizar um fator de diferenciação que não possuiu correlação lógica com a disciplina da filiação, haja vista que a relação conjugal não pode determinar a sorte do vínculo de filiação.

Observando a natureza, evidencia-se que entre o filho legítimo e o ilegítimo ela não operou de maneira diversa. Ambos foram provenientes de uma relação sexual em que se realizou a fecundação, os dois tendo um período de gestação no ventre materno e vindo ao mundo igualmente, por meio do parto.

Mas, neste último momento, o direito interferia para dizer, então, se aquele neonato seria filho legítimo ou ilegítimo, segundo a noção que interessava para a sociedade, por sinal, francamente oposta às relações não amparadas pelo matrimônio.

Esta espécie de regra jurídica podia satisfazer à sociedade de 1917, ano de promulgação do Código Civil, resultando da aplicação de idéias falsas sobre o verdadeiro. Mistificava-se a verdade material, para dela tirar os seus proveitos, seja pelo benefício patrimonial e social conferido ao filho legítimo, seja pela ocultação do filho havido fora do casamento com o estigma da ilegitimidade.

Por sinal, o fator de diferenciação dos filhos legítimos e ilegítimos em sentido amplo não estava em elementos inerentes a eles próprios, mas sim num critério exterior, qual seja, a existência ou não de união matrimonializada dos genitores. Conseqüentemente, o segundo critério oferecido por Celso Antonio Bandeira de Mello não era obedecido.

No que concerne ao derradeiro critério - a previsão na Constituição da desigualação — obviamente que consagrando a Constituição de 1988 o 
princípio da igualdade de todas as categorias de filhos, qualquer desrespeito ao sistema constitucional afasta a pretendida igualdade.

Isto posto, a utilização de uma igualdade meramente formal, baseada no simples tratamento igual dos iguais e desigual dos desiguais, não tem a importância outrora obtida, constatando-se a injustiça do Código Civil ao tratar os filhos segundo rígidos critérios.

O tratamento do antigo filho ilegítimo, entretanto, passa a gozar de maior justiça, com a inserção da igualdade, sendo um ensinamento sobre a responsabilidade e consideração para com o próximo, além de impor a ética na procriação.

Não resta dúvida de que o mau tratamento do filho ilegítimo não pode favorecer a família, representando uma inadequada utilização do direito para castigar o filho, quando os responsáveis pela geração ficariam isentos de implicações.

Lembre-se, aliás, que entre os deveres que incidem sobre o genitor e seu filho legítimo está a responsabilidade pelos danos causados pela omissão do dever de guarda e vigilância. Os filhos ilegítimos, inobstante, por mais que praticassem atos lesivos a outrem, a vítima não poderia responsabilizar os genitores naturais do filho, apenas a mãe em caso de reconhecimento.

A proteção da família legítima deixou, desta forma, de operar por meios ruins - em detrimento dos filhos tidos como ilegítimos - mesmo ainda sendo a família construída pelo casamento a base mais importante da sociedade, como se depreende do favorecimento constitucional ao casamento.

Não há que se negar, destarte, que ofendia-se ao princípio da isonomia, discriminação odiosa e interesseira que se viu amputada pela Constituição Federal de 1988.

Adotando-se as explanações realizadas sobre a igualdade formal e material, deve-se observar a maneira utilizada pela Constituição ao se referir sobre a identidade de "direitos e qualificações entre os filhos havidos ou não da relação do casamento".

A lição trazida por Carlos Maximiliano ${ }^{52}$ ao afirmar que a lei não contém palavras inúteis merece atenção. 
Sendo assim, a identidade de direito não corresponde a uma identidade de qualificações.

Precisamente, o termo "qualificações" se refere à denominação atribuída à filiação, não podendo mais serem usadas as expressões ilegítimo, natural, espúrio, bastardo, adulterino e incestuoso.

Quanto aos direitos, pode-se pensar que seria o antigo direito do filho ilegítimo pleitear seu reconhecimento, seja voluntariamente ou através de investigação.

Todavia, esta interpretação fica a meio caminho da igualdade material, finalidade nítida da Constituição ao fazer referência sobre os "mesmos direitos".

Assinale-se que, em detrimento dos filhos nascidos fora do casamento, não poderá ser estabelecida qualquer discriminação de regime jurídico que se consubstancie em desfavor ou desproteção infundada, injustificada segundo o dado concreto de igualdade.

Das três leis posteriores à Carta Magna que versaram sobre a filiação, em todas nota-se que aquela visão rançosa e tradicionalista do Código Civil deixou de existir, de tal forma, que todas as disposições contrárias ao princípio constitucional estão revogadas, restando uma lacuna que cabe ao juiz supri-la de acordo com as necessidades do caso concreto.

\section{Efeitos da igualdade de filiação}

A doutrina nacional tem se mantido reservada, salvo exceções, quanto às opiniões e sugestões que se tornaram possíveis fazer em matéria de filiação, levando-se em consideração, que para abarcar o princípio constitucional de igualdade de filhos, deve ser reformulada a disciplina antes fixada pelo Código Civil.

Na tentativa de transpor esta dificuldade primária, serão apresentadas considerações acerca da nova realidade e tendências do sistema de filiação, após a Constituição de 1988.

52 Carlos Maximiliano, Hermenêutica e aplicação do direito, Rio de Janeiro, Forense, 1980 , p. 250-251. 
Com esta finalidade, as análises dos temas versarão, no que for possivel, sobre o sistema originário, desta feita brevemente, para depois abordar a Constituição e leis ordinárias posteriores a ela, expondo-se a atual posição legislativa.

Em seguida, serão exibidas algumas opiniões doutrinárias, acompanhadas dos sistemas de filiação no direito comparado, com inclusão de jurisprudências atuais e, por fim, as tendências e sugestões de nosso entendimento.

\section{Premissas dos sistemas}

Como já foi dito e exposto, o Código Civil aplicou em matéria de família o princípio da unitariedade, embasando-se totalmente no matrimônio para beneficiar os filhos havidos sob este tipo de união com múltiplos direitos, contidos todos na expressão favor legitimitatis.

A Constituição, por sua vez, desfez o sistema unitário e institui três formas de entidade familiar: o casamento, a união estável e a comunidade de $\mathrm{um}$ ascendente com os descendentes.

Determinou, ainda, a igualdade de todas as espécies de filhos, tanto de direitos como de qualificações, assim como previu o principio da paternidade responsável.

No Estatuto da Criança e do Adolescente, ${ }^{53}$ Lei $n^{\circ} 8.069 / 90$, entre outras inovações, regulamentou-se a família natural, compreendendo-a como uma união estável ou comunidade de pai e descendente. A Lei $\mathrm{n}^{\circ}$ $8.560 / 92$, por sua vez, instituiu a averiguação oficiosa da paternidade e ampliou as formas do reconhecimento voluntário da paternidade.

No aspecto doutrinário, os professores José Lamartine e Francisco Muniz $^{54}$ dispõem que as reformas, de uma maneira geral, no direito contemporâneo, estabeleceram um respeito à verdade biológica da filiação e, ao mesmo tempo, tutelaram a verdade sociológica e afetiva com conside-

53 Capítulo III, Seção II. artigos. 25-27.

5.4 José Tamartine e Franscisco José Ferreira Muniz. Direito de Familia (direito matrimonial). Porto Alegre. S. Fabris. 1990, p. 37-49.

R. Fac. Direito. Curitiba, a.27, n.27, 1992/93. p.141-202 
rações sobre a estabilidade emocional e social dos filhos, de modo que a predominância típica da verdade biológica restou afastada.

Adotando o sentido moderado de igualdade, João Baptista Villela ${ }^{55}$ pondera que a Constituição reafirmou a preeminência do casamento como expressão da vida familiar, mantendo este instituto como basilador da filiação.

Em termos de Direito Comparado, o Direito de Família da França merece destaque por ser o ordenamento que mais avançou em matéria de filiação, encontrando-se como princípios fundamentais a igualdade entre os filhos, ${ }^{56}$ a busca da verdade biológica e ponderação com a verdade afetiva, a atenuação da presunção de paternidade, a investigação de paternidade com mais legitimados ativamente e, finalmente, a posse do estado de filho, como o "voto de minerva", na solução do conflito de filiação. ${ }^{57}$

Apanhando-se todas estas noções gerais sobre a filiação, faz-se necessária a criação pelo legislador brasileiro, de um sistema que busque a verdade biológica, proposição que tem correlação lógica com o princípio da paternidade responsável previsto na Constituição, da mesma forma que, em respeito ao princípio da eqüidade dos filhos, deve vedar qualquer discriminação sobre as várias espécies adotadas pelo direito anterior e, acima de tudo, estabelecer como preponderante o favor filii, isto é, o favorecimento da filiação.

Consoante estes princípios básicos, as disposições da Constituição e do Estatuto da Criança e Adolescente, além das opiniões dos professores José Lamartine e Francisco Muniz, são integralmente aplicáveis como corolários básicos da nova realidade.

Quanto à opinião do professor João Baptista Villela, concordamos que o casamento, por seu tradicionalismo, sempre estará em preponderância sobre as outras entidades familiares, até mesmo pela insegurança da sociedade em inovar com uniões pouco usuais.

55 João Baptista Villela, Reconhecimento.., op. cit., p. 73.

56 Ressalte-se, entretanto, que o direito de filiação francês não igualou totalmente os filhos, deixando uma reserva diferenciadora quanto aos direitos sucessórios dos filhos adulterinos e impedindo o reconhecimento dos filhos incestuosos absolutos (incesto na linha reta de parentesco consangüíneo).

57 Hipótese em que o julgador tem que escolher se aplica ao caso concreto o que é determinado pela lei, pela natureza ou pelo aspecto sócio-afetivo da questão. 


\section{Do parentesco}

A observação do sistema do Código Civil denota que as relações de parentesco giravam em torno da legitimidade, concebendo-se a espécie legítima, ilegítima e civil.

Mas, se havia concordância com o sistema vigente à época, hoje a igualdade de filhos e a ampliação das formas de família afasta a possibilidade de sequer pensar nas espécies legítima ou ilegítima, tampouco aplicar as antigas regulamentações no caso concreto.

Parentesco, no direito contemporâneo, somente admite a classificação de consangüíneo ou civil, sem nenhuma discriminação quanto à legitimidade, tendo em vista que a própria noção de legitimidade embasadora da ultrapassada divisão do parentesco não possui mais existência, conforme decorre do princípio da igualdade dos filhos.

\section{Espécies de filhos}

Tradicional na qualificação e classificação dos filhos, o sistema originário do Código Civil concebia a filiação consangüínea como legítima ou ilegítima, incluindo nesta os filhos naturais, adulterinos e incestuosos. $^{58}$

No aspecto legislativo, a Constituição expressamente dispôs a vedação de designações discriminatórias, referindo-se, é claro, justamente à tal classificação.

No limiar de 1992 , a Lei $n^{\circ} 8.560$, em cotejo às disposições Constitucionais, previu a aplicação do direito de silêncio quanto à origem da filiação, ${ }^{59}$ de forma que as qualificações diferenciadoras de outrora ficaram manifestamente proibidas.

No campo doutrinário, inúmeros juristas defenderam a proibição de qualificação discriminatória, ressaltando dentre eles a notável opinião de Sérgio Gischkow Pereira, ${ }^{60}$ pelo qual as expressões do Código Civil

58 A respeito, vide item I. 2.

59) Artigo 5\%.

60) Sérgio Gischkow Pereira, "Algumas questões de Direito de Família na nova Constituição". Revista dos Tribunais, 1989(636), p. 247/53.

R. Fac. Direito. Curitiba. a.27, n.27. 1992/93.p.141-202 
somente poderão ser utilizadas para fins didáticos e para tipologização doutrinária.

Destarte, aproveitando do ensinamento trazido pelo doutrinador citado, justifica-se toda a explanação antes realizada sobre o sistema anterior, desde que teve um cunho didático e explicativo.

Todavia, se diante da proibição constitucional as denominações discriminatórias originárias do Código Civil não devem mais ser aplicadas, cabe sugerir uma classificação dos filhos adequada com as inovações constitucionais.

Neste sentido, pode-se falar em filhos havidos dentro do casamento, para designar aqueles encampados pela presunção de paternidade devido ao casamento dos genitores.

De outro lado, os filhos provenientes das uniões estáveis, enquanto entidade familiar reconhecida e protegida pelo estado, devem ser chamados de filhos havidos dentro da união estável, de acordo com os argumentos da exposição que adiante será desenvolvida sobre a aplicação da presunção de paternidade no concubinato.

Outrossim, para se referir aos antigos filhos adulterinos, incestuosos e naturais, a designação de filho havido fora do casamento e havido fora da união estável apresenta-se adequada ao repelir discriminação, mas esta denominação apenas será aplicável aos casos em que não haja uma união estável ou casamento entre os pais.

Com estas sugestões, espera-se que os conceitos do direito anterior sejam superados para permitir a aplicação do novo estatuto igualitário de filiação, principalmente para refutar a noção de filiação legítima que estava presente no revogado direito civil brasileiro.

\section{Da legitimação}

Um dos institutos que mais beneficiavam a filiação ilegítima e, em especial, os filhos naturais, era a legitimação por casamento posterior dos pais, haja vista que simbolizava a ponte de passagem do mundo da ilegitimidade para a legitimidade. 
Abandonando a noção do casamento como monopólio da concepção jurídica de família, não há como subsistir tal previsão, de tal maneira que o filho havido fora do casamento passa imediatamente a ser denominado juridicamente como "filho existente na união estável".

Exprimindo a dificuldade atual de aplicar a legitimação, a Lei 8.560/92 impediu que ela ou o reconhecimento se opere na ata do casamento. ${ }^{61}$

Como exceção à inaplicabilidade da legitimação ao direito atual, surge a hipótese na qual inexista entre os genitores qualquer uma das entidades familiares (casamento ou união estável).

Apenas a denominação de "legitimação" não pode permanecer, pois não há mais sequer parentesco legítimo ou ilegítimo, podendo-se designar como "inclusão do filho no casamento ou na união estável", desde que não haja nenhuma destas entidades familiares.

\section{Da presunção de paternidade}

O tema de maior dificuldade de adequação ao princípio de eqüidade entre as espécies de filhos consiste na presunção de paternidade, haja vista que a criação deste instituto visou beneficiar os filhos concebidos na constância do casamento.

Tanto é verdade, que possuía o Código Civil um sistema de causas determinadas para afastar a presunção, bem como a ação para derrubá-la contava com prazo exíguo e legitimidade exclusiva do pai presumido.

A presunção de paternidade, como posta no Código, tem uma natureza intermédia, ou seja, admitindo prova em contrário, mas nos estritos limites legais. ${ }^{62}$

A presunção de paternidade incide sobre dois aspectos, a coabitação e a geração. Sendo assim, apesar da aparente unidade, a composição da presunção de paternidade é dupla, abrangendo a presunção de coabitação e de geração.

61 Artigo $3^{\circ}$, caput.

62 A respeito, vide item I. 2.

R. Fac. Direito. Curitiba. a.27. n.27. 1992/93. p.141-202 
Nas legislações ordinárias que sucederam a Constituição, não houve disposição a respeito, cabendo somente relembrar que a união estável foi reconhecida como entidade familiar no próprio texto constitucional.

A doutrina produziu algumas considerações sobre a presunção.

Como posição conservadora, cabe mencionar a opinião de João Franklin Alves Felipe, ${ }^{63}$ segundo o qual a derrubada da presunção ainda deveria obedecer aos mesmos casos elencados no artigo 340 do Código Civil.

Em perspicaz estudo sobre a paternidade presumida, o professor Luiz Edson Fachin ${ }^{64}$ expressa a opinião de Hegnauer, pelo qual a presunção pater is est opera como resíduo diferenciador entre a situação dos filhos tidos dentro do casamento e fora dele.

Além disso, o professor Doutor argumenta que, havendo um juízo de verossimilhança improvável, a presunção não deve incidir sobre o nascimento do filho.

No caso de inocorrerem as hipóteses de cessação, expõe ele que melhor seria permitir o ataque direto da presunção de paternidade, por exemplo, na investigação de paternidade ou mesmo com o reconhecimento voluntário.

Ao marido caberia uma ação para restabelecer a presunção, que poderia ter cessação com a Posse do Estado de Filho em favor de outrem que não o pai, além da separação de fato, à época da concepção, concluindo que a conformação da presunção pater is est deve ser atenuada.

De suma importância, entretanto, são as considerações trazidas pelo mencionado professor ao tratar do concubinato em nota explicativa, ${ }^{65}$ informando que o estatuto da legitimidade foi afastado com a reforma constitucional e a presunção passou a informar tãosomente o estabelecimento da paternidade, o que equivaleria em reduzir o seu alcance.

Por outro lado, transcreveu parte de um recurso especial julgado no Supremo Tribunal Federal em que se denota a tentativa de transposição da regra para o âmbito da união estável, concluindo, por fim, que o importante

63 Jorge Franklin Alves Felipe, "A nova Constituição e seus reflexos no direito de família", Revista Forense, Rio de Janeiro, 1988(304), p. 93/8.

64 Luiz Edson Fachin, Estabelecimento..., op. cit., p. 16 e 167-9.

65 Luiz Edson Fachin, Estabelecimento..., op. cit., p. 68. 
elemento daquele julgamento é a idéia de comunhão de vida na base da presunção pater is est.

Também versou sobre a matéria João Francisco Moreira Viegas ${ }^{66}$ que, embora tenha realizado a tarefa em poucas linhas, não deixou de manifestar o seu pensamento no sentido de ser aplicada a presunção de paternidade para o concubinato que tenha se efetivado no período legal da concepção, inclusive com referência ao artigo 75 do Código Civil Cubano que teria aplicado esta solução. ${ }^{67}$

Quanto ao direito comparado, importante fonte de auxílio para solucionar o sistema que ainda está para ser legislado, começando-se por Portugal, cabe informar que em virtude da preservação e procura da verdade biológica, estabeleceu que os casos de cessação da presunção devem obedecer a um juízo de probabilidade, inclusive com a possibilidade da mãe indicar ao oficial do registro civil o nome de terceiro e não do marido como pai.

Na Suiça, a presunção foi mantida, mas com uma preocupação voltada ao período da concepção, pois sendo demonstrado que na época da concepção não ocorreu coabitação, seria possivel repelir a presunção.

Na Bélgica, a presunção possui um caráter relativo, cessando automaticamente desde que esteja autorizado judicialmente o terceiro reconhecente a assim proceder.

Quanto à área jurisprudencial, já se entendeu que a separação de fato possibilita a rejeição da incidência da presunção, ${ }^{68}$ demonstrando a sua relativização diante de fatos contrários à sua aplicação.

66 João Francisco Moreira Veigas. "A filiação fora do casamento na nova Carta da República", Revista dos Tribunais, São Paulo. 1988(634), p. 70/1.

67 Vide a referência já realizada sobre a Constituição de Cuba e o princípio da igualdade de filhos, item VI, "Da igualdade na filiação".

68 Investigação de paternidade-inexistência de obstáculo legal. pela eventual condição jurídica de casados, com terceiros. do suposto Pai e da Mãe do autor, à época da concepção-carência inocorrente-cf/88. art. 227. § $6^{\circ}-\mathrm{ccb}$, art. 337. (indica Jurisprudência). Em face dos termos do art. $227 . \S 6^{\circ}$ da cf $/ 88$, descabe falar em carência da investigatória de paternidade pela eventual condição de casados. com terceiros. do suposto pai e da mãe do autor (Tribunal de Justiça de São Paulo, $2^{\text {a }}$ Câmara Cível. apelação cível 125.676-1. Rel. Des. Cezar Peluso, julgado em 13.11.90. in.Jurisprudência Brasileira. v. 164. Juruá. Curitiba. 1992. p. 211).

R. Fac. Direito. Curitiba. a.27.n.27. 1992/93. p.1+1-202 
Com efeito, a separação de fato, um dado concreto, possibilitou o afastamento da presunção, confirmando a opinião do professor Luiz Edson Fachin de que a base da presunção é a comunhão de fato, o que não ocorreu no caso transcrito.

Em caráter ainda mais inovador, perfeitamente de acordo com os ditames constitucionais, a Primeira Câmara Cível do Tribunal de Justiça de São Paulo considerou a nova natureza da presunção, ${ }^{69}$ afirmando expressamente que a presunção de paternidade sobre o marido da mãe tem caráter relativo.

De fato, não só a presunção teve sua natureza relativizada, como também dispęnsou-se a prévia impugnação da presunção para o exercício investigatório de paternidade, o que evidencia a busca da Verdade Biológica, decisão muito louvável e de extrema correção, verdadeira preciosidade nos meios jurídicos.

A presunção de paternidade não deve mais ficar restrita à filiação havida dentro do casamento; do mesmo feitio, deve incidir sobre os filhos que provenham de uniões estáveis, ou seja, a presunção deve abranger o concubinato.

Analise-se a dupla esfera da questão, levando-se em consideração que a presunção de paternidade que sobrevém aos filhos havidos dentro do casamento é composta por duas presunções, como já dito, a de coabitação e a de geração.

69 Investigação de Paternidade - Mãe do autor casada com terceiro à época da concepção Mulher con cubinada com o Réu, neste período, em face de o Marido estar preso - caráter relativo da presunção de paternidade no curso do casamento, em especial se inexiste coabitação - pedido juridicamente possível, também em razão da Cf/88, art. $227, \S 6^{\circ}-$ CCB, art. 337. A presunção de que o pai é o marido da mãe tem, atualmente, caráter relativo porque, mais do que a existência legal do casamento, exige-se que haja convivência efetiva para a presunção poder ser aplicada. Investigação de Paternidade casamento da Mãe do autor com terceiro à época da concepção - desnecessidade de o marido propor ação negatória ou repudiar formalmente a paternidade, como condição da investigatória. Atualmente, mesmo estando a mãe do autor casada com terceiro à época da concepção, não se exige que o marido proponha ação negatória ou repudie formalmente a paternidade como condição para a investigatória (Ag. de Inst. 127.323-1, Rel. Des. Roque Komatsu, julgado em 13.02.90. in Jurisprudência Brasileira, v. 160, Juruá, Curitiba, 1991, p. 321). 
Desde que a Constituição de 1988 estabeleceu uma mudança da guarida fornecida pelo direito de família, deixando a exclusividade do vínculo matrimonial para tutelar os interesses dos filhos, a procriação ocorrida no transcurso de uma união estável não pode ser diferenciada em tratamento dos filhos havidos no casamento.

Logo, aquele resíduo discriminador que seria a presunção pater is est, deve ser aplicado também para a união estável, mantendo a sua função

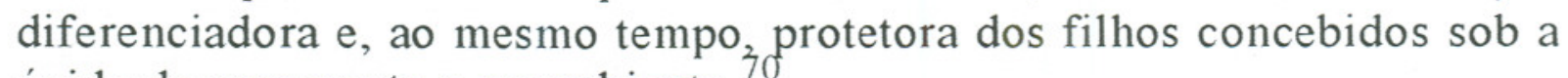
égide do casamento e concubinato.

A jurisprudência busca justamente nos fundamentos da presunção de paternidade e da sua impugnação a motivação para a procedência da investigação de paternidade em caso de concubinato.

Na prática, o caminho percorrido pelo julgador é o mesmo daquele estipulado para a presunção, ou seja, atentando-se para os elementos constitutivos da presunção pater is est, então inexiste impedimento para aplicar diretamente a presunção aos casos de união estável, especialmente se

70 Como exemplo da coincidência entre o caminho percorrido para caracterizar o concubinato e os fundamentos da presunção de paternidade. transcrevemos as seguintes ementas com grifos nossos: in vestigação de paternidade - coincidência da concepção do autor com o período de relações sexuais entre a mãe e o suposto pai - apreciação da prova - paternidade não excluida pelo exame hematológico - exceção do plurium concubentium não provada - conjunto probatório suficiente - recurso improvido... Para o reconhecimento da paternidade com base no relacionamento sexual contemporâneo da concepção, ante a impossibilidade da prova direta, bastam indicios e presunções, desde que veementes e persuasivos (Tribunal de Justiça de Mato Grosso do Sul. $1^{\text {" Turma }}$ Cível, Apelação Cível 27.214-8. Rel. Des. Josué de Oliveira. publicado em 31.03.92. in Repertório IOB de Jurisprudência. RJ (3), 1993, n $\left.{ }^{\circ} 7022\right)$. Investigação de paternidade - convivência no período da concepção - confissão do apelante. - "exceptio de plurium concubentium" indemonstrada - recurso improvido. ... A prática da conjunção carnal, no período da concepção da Apelada, entre sua genitora e o Apelante, aliada à inexistência do "plurium concubentium" é suficiente nos termos da Lei Civil, para atestar a paternidade reinvidicada na inicial (Tribunal de Justiça do Espírito Santo. $1^{\text {a }}$ Câmara Cível, Apelação Cível $\mathrm{n}^{\circ}$ 18.938. Rel. Des. Arione Vasconcelos Ribeiro. in Repertório IOB de Jurisprudência. RJ (3). 1993, n 6964). Investigação de paternidade - Prova - Relacionamento afetivo entre a mãe do autor e o suposto pai na época da concepção e bom comportamento daquela satisfatoriamente demonstrados Aceitabilidade da provatécnica, em vista da compatibilidade de tipagem sanguinea entre investigando e investigado - "Exceptio plurium concubentium" não reconhecida (Tribunal de Justiça de São Paulo, $1^{a}$ Câmara Cível. Apelação Cível 127.674-1. Rel. Des. Euclides de Oliveira. in Revista dos Tribunais, v. 663:81. 1991).

R. Fac. Direito, Curitiba. a.27. n.27. 1992/93, p.141-202 
considerada a necessidade de ser protegida a filiação com plena e irrestrita igualdade.

A conseqüência deste entendimento ampliativo da incidência da presunção é somente antecipar a apreciação dos seus elementos, deixando de fazer a sua aplicação em sede jurisdicional para efetuá-la imediatamente com o fato do nascimento.

Acrescente-se que a necessidade de ser mitigada a presunção, como asseverou a decisão pretoriana antes mencionada, torna mais fácil sua ampliação, abandonando o rígido sistema para incluir também a união estável.

Além disso, em conformidade com o aspecto levantado pelo professor Fachin, o alcance mais limitado da presunção de paternidade, em virtude de ser rejeitado atualmente o seu antigo propósito, qual seja, de instituir a legitimidade, justifica ainda mais que a presunção encampe também o concubinato, só não o fazendo com a comunidade entre um dos ascendentes e os descendentes, porque desta família pós-nuclear não resulta procriação e, portanto, não há o que se falar em presunção.

A viabilidade prática desta ampliação da presunção de paternidade não encontra nenhum empecilho na normalidade dos casos, somente exibindo maior complexidade perante o surgimento de uma pendência judicial, mas como costumeiramente o julgador já passava pela seara da presunção pater is est, para considerar procedente a investigação, nada dificultará a proteção imediata dos filhos havidos dentro da união estável com a incidência da presunção de paternidade sobre eles.

Isto propicia, como não poderia deixar de ser, a definição pelo legislador da união estável, do seu tempo mínimo para estabilidade, contudo, não refuta a sugestão só porque o legislador ainda não aplicou a presunção para a união estável, cabendo ao magistrado a tarefa de suprir a lacuna com criatividade e, acima de tudo, bom senso.

Note-se, por fim, que tal ampliação da presunção não enseja necessariamente uma ofensa à referida preeminência do casamento defendida pelo professor João Baptista Villela, ${ }^{71}$ tendo em vista que é preferível proteger imediatamente os filhos havidos dentro da união estável do que

71 João Baptista Villela, Reconhecimento..., op. cit., p. 73. 
esperar o reconhecimento voluntário ou judicial para conceder os direitos e deveres que já deveriam ter nascido junto com o filho.

Arrematando o assunto, cabe mencionar que sob a presunção, deve suceder um caráter relativo, admitindo livremente a prova em contrário, levando-se em consideração que esta constitui a forma correta de permitir a busca da verdade biológica.

A relativização da presunção impede que a realidade seja encoberta com presunções fictícias, principalmente nos casos dos antigos filhos adulterinos a matre, os quais eram presumidos como sendo filhos do marido da mãe.

Para tal desiderato é imprescindível que a prova para afastamento da presunção seja livre e o prazo da respectiva ação amplo, viabilizando a busca da verdade natural pelo meios jurídicos ou, em outros termos, aproximando o sistema jurídico da natureza.

\section{Reconhecimento de paternidade ${ }^{72}$}

Disciplinou o Código Civil que o reconhecimento de paternidade estaria limitado aos filhos naturais, sofrendo depois modificações que findaram por permitir não só o reconhecimento dos filhos naturais, mas também dos filhos adulterinos, se preenchido o requisito legal de haver separação de fato há mais de cinco anos, ou dissolução do casamento.

Nesta área, entretanto, o legislador pós-constituição não permaneceu inerte e se encarregou de disciplinar.

A Lei $n^{\circ} 7.841 / 89$ revogou expressamente o artigo 358 do Código Civil, pelo qual os filhos adulterinos e incestuosos não poderiam ser reconhecidos.

Posteriormente, o Estatuto da Criança e do Adolescente regulamentou as formas de reconhecimento dos filhos havidos fora do casamento, prevendo que poderia ser concretizada pelos pais, conjunta ou separada-

72 Será objeto de apreciação o reconhecimento voluntário de paternidade, tendo em vista que o reconhecimento judicial é tema para ser abordado no item seguinte que trata da investigação de paternidade.

R. Fac. Direito. Curitiba. a.27, n.27. 1992/93. p.141-202 
mente, no próprio termo de nascimento, por testamento, mediante escritura ou outro documento público, qualquer que seja a origem da filiação. ${ }^{73}$

Além disso, o Estatuto atribuiu características específicas ao reconhecimento do estado de filho, entendendo-o como direito personalíssimo, indisponível e imprescritível, podendo ser exercitado contra os pais ou seus herdeiros, sem qualquer restrição, observado o segredo de justiça. ${ }^{74}$

Não satisfeito com a regulamentação já havida, o legislador tornou a dispor sobre o reconhecimento na Lei 8.560, de 29 de dezembro de 1992, desta feita, modificando sobremaneira as anteriores possibilidades de fazêlo.

Instituiu quatro meios de reconhecimento dos filhos havidos fora do casamento: por registro de nascimento, escritura pública ou escrito particular, testamento e por manifestação expressa e direta perante o juiz.

A doutrina a respeito do reconhecimento apresenta várias opiniões, todas produzidas sob a vigência da legislação que antecedeu a Lei $\mathrm{n}^{\circ}$ $8.560 / 92$, mas que apresentam relevância para o presente estudo.

Manifestou o professor Luiz Edson Fachin ${ }^{75}$ que o reconhecimento voluntário pode se dar na constância da sociedade conjugal, pensamento compartilhado por Jorge Franklin Alves Felipe. ${ }^{76}$

Mas este último, em sentido avesso ao anseio de alcançar a verdade biológica, entendeu que o reconhecimento não pode ser direto, devendo ser mantido no termo de nascimento o nome do pai presumido, posição que se confronta com a tomada pelo professor Doutor Fachin ao preferir que seja omitido o nome do pai presumido, quando a mãe aponta terceiro como pai ao oficial do registro, em virtude da separação de fato.

Tanto Fábio Mário de Mattia, ${ }^{77}$ como Walter Moraes por aquele mencionado, opinaram que a eqüidade dos filhos em direitos tem por conseqüência mais notável o fato de todos os filhos extramatrimoniais,

73 Artigo 26, caput, da Lei ${ }^{\circ} 8.069 / 90$.

74 Artigo 27, Lei ${ }^{\circ} 8.069 / 90$.

75 Luiz Edson Fochin, Estabelecimento..., op. cit., p. 168.

76 Jorge Franklin Alves Felipe, A nova..., op. cit., p. 95.

77 Fábio Mário de Mattia, "Investigação de paternidade: alimentos, filiação e conseqüências da nova norma constitucional", Repertório IOB de Jurisprudência, $\mathrm{n}^{\circ} 3 / 89,1^{\text {a }}$ quinzena de fevereiro, 1989 , p. 48-49. 
qualquer que seja a espécie da filiação dita ilegítima, poderem ser reconhecidos.

Por outro lado, Fábio Mattia e Yussef Said Cahali ${ }^{78}$ se mostraram favoráveis à possibilidade de reconhecimento de filho incestuoso, o que era absolutamente vedado antes da Constituição de 1988.

Feitas estas colocações, deve-se observar que o direito dos filhos ao reconhecimento não pode sofrer qualquer restrição. O reconhecimento pode ser realizado independentemente da existência de vínculo anterior da mãe com terceiro que não o pai biológico, até porque o princípio da paternidade responsável não permite limitação.

A existência da presunção de paternidade não pode obrigar o oficial ao registro do neonato como sendo filho do pai presumido, haja vista que significaria a manutenção da verdade jurídica enquanto a paternidade responsável determina que o estabelecimento da paternidade se dê em conformidade com a verdade biológica.

A Lei $n^{\circ} 8.560 / 92$ dispôs que o reconhecimento pode ser realizado no próprio termo de nascimento, ${ }^{79}$ instituindo a investigação oficiosa, quando só a maternidade constar do registro.

Denota-se, portanto, que, sendo possivel reconhecer o filho no assento de nascimento, igualmente será possível afastar a presunção de paternidade pelas declarações da mãe adúltera, confirmando a nossa posição que desvincula o reconhecimento de paternidade dos efeitos da presunção, consoante o caráter relativo da presunção antes exposto.

Tal entendimento é corroborado pelo Provimento 355/89, do Conselho Superior da Magistratura de São Paulo, ao prever que no caso da mãe casada ter filho extramatrimonial, a menção do nome do suposto pai deve ser feita em apartado, não podendo constar do assento de nascimento, a menos que, posteriormente, ocorra a confirmação expressa da paternidade pelo indigitado pai. $^{80}$

78 Yussef Said Cahali, "A situação dos filhos havidos fora do casamento e a nova Constituição", Revista dos Tribunais, 1989(643), P. 239/41.

79 Artigo $1^{\circ}$, inciso I.

80 Theotônio Negrão, Código Civil, nota 1 ao artigo $1^{\circ}$ da Lei n ${ }^{\circ} 8.560 / 92$. São Paulo. Malheiros, 1993, p. 562.

R. Fac. Direito, Curitiba, a.27, n.27, 1992/93, p.141-202 
Portanto, a opinião do Doutor Fachin se coaduna perfeitamente com o referido provimento, ao manifestar que é preferível omitir o nome do suposto pai, no termo de nascimento, em caso de mãe adúltera.

No que tange ao reconhecimento por escrito particular ${ }^{81}$ disposto pela Lei $n^{\circ} 8.560 / 92$, mesmo sendo previsto o arquivamento em cartório, não constitui o meio adequado para se realizar um ato de soberba importância, principalmente em razão da irrevogabilidade estabelecida no caput do artigo $1^{\circ}$, tendo em vista que afasta a estabilidade e firmeza que se encontra no reconhecimento procedido por instrumento público.

Com relação ao reconhecimento incidental em testamento, ${ }^{82}$ este instituto jurídico é tão parcamente utilizado no cotidiano nacional, que praticamente levou a previsão legal à inoperância concreta. A simples viabilidade do reconhecimento ser operado por escritura pública, de imediato tornou a menção legal ao testamento quase desnecessária.

Quanto à possibilidade do reconhecimento se proceder por manifestação expressa e direta perante o juiz, ${ }^{83}$ como pondera Marcelo Domans$\mathrm{ki},{ }^{84}$ nada impede que se dê perante um juiz sem competência material para tanto, por exemplo, numa reclamatória trabalhista, em que o reclamante seja perguntado sobre a existência de filhos, para se confirmar a procedência do pedido de salário-família, indicando ele o nome e qualificação do filho que o individualiza e torna certa a identidade, caso em que estaria concretizado o reconhecimento por manifestação expressa perante o juiz.

Em relação ao reconhecimento na constância da sociedade conjugal, a jurisprudência firmou entendimento favorável à sua possibilidade, fundando-se na aplicação do princípio da igualdade de filhos. ${ }^{85}$

81 Artigo $1^{\circ}$, inciso II, $2^{a}$ parte.

82 Artigo $1^{\circ}$, in ciso III.

83 Artigo $1^{\circ}$, inciso IV.

84 Marcelo Domanski, "Algumas considerações acerca do reconhecimento espontâneo de filho não matrimonial na constância do casamento do pai em face da Constituição Federal de 1988 e da Lei n ${ }^{\circ} 8.560 / 92 "$ ", Monografia semestral apresentada na disciplina de Direito Civil II do Curso de Pós-Graduação em Direito da Universidade Federal do Paraná, Setor de Ciências Jurídicas, em 07.06.93.

85 Filiação Ilegítima - Filho Adulterino - Reconhecimento na constância do casamento Ação anulatória do Registro Civil - Inadmissibilidade ante a revogação do art. 358 do CCB pelo art. $227, \S 6^{\circ}$ da Constituição Federal. Ementa Oficial: Não deve prosperar a ação anulatória de registro de nascimento de filho adulterino, porquanto o art. $227, \S$ $6^{\circ}$, da nova Constituição Federal, ao determinar que teriam os filhos, havidos ou não 
Desta forma, a existência de sociedade conjugal não obsta ao reconhecimento voluntário do filho havido fora do casamento.

Contudo, realizando-se o reconhecimento, haverá um conflito de filiação diante do confronto entre a paternidade presumida e a reconhecida, podendo ser utilizada a via judicial de acordo com os interesses dos envolvidos e, neste caso, a posse do estado de filho ${ }^{86}$ deverá intervir para fornecer ao julgador o caminho correto.

\section{Investigação de paternidade}

Como anteriormente fora mencionado, ${ }^{87}$ a investigação de paternidade era o instrumento para os filhos ilegítimos naturais serem reconhecidos. Os adulterinos, mesmo no último estágio legislativo antes da Constituição, somente poderiam demandar a investigação se houvesse separação de fato de mais de 5 anos ou dissolução da sociedade conjugal. Os incestuosos, por último, sempre estiveram impedidos de postular a investigação de paternidade.

No momento posterior à Constituição, a Lei ${ }^{\circ} 8.560 / 92$ instituiu a averiguação oficiosa, ${ }^{88}$ o que efetivamente demonstra a busca da verdade biológica e estabelecimento da paternidade responsável, cumprindo com as determinações constitucionais e, ao mesmo tempo, inovando com o sistema anterior.

Mas, de certa forma, fixou um procedimento ex officio do juiz, apesar desta iniciativa oficial ser efetuada em procedimento de jurisdição voluntária e, portanto, de natureza administrativa, tanto assim que determina somente a notificação do suposto pai, e não a sua citação.

Nesta hipótese - averiguação oficiosa - a figura da mãe aparece como o elemento central, responsável pelo desencadeamento de uma operação

da relação do casamento. os mesmos direitos e qualificações, derrogou tacitamente o art. 358 do Código Civil. que impedia aquele reconhecimento (Tribunal de Justiça de Minas Gerais. $3^{\text {a }}$ Câmara Cível. Apelação Cível 77.361-3. Rel. Des. Régula Peixoto, julgado em 09.03.89. in Jurisprudência Brasileira. V. 149-261. Juruá, Curitiba).

86 Item VII.1. do presente trabalho.

87 Vide item I. 2.

88 Artigo $2^{\circ} \mathrm{e} \S \S$.

R. Fac. Direito. Curitiba, a.27. n.27. 1992/93. p.141-202 
para encontrar a paternidade do filho, tendo em consideração, que somente ela poderá apontar o suposto pai.

O único equívoco do legislador, entretanto, foi conferir legitimidade ao Ministério Público para intentar a investigação, quando o suposto pai não atender à notificação ou negar a paternidade, mesmo sendo uma solução consagrada em termos de direito comparado, em especial na França e em Portugal.

A previsão legal, em primeiro plano, afronta o princípio da inviolabilidade da vida privada, previsto no artigo $5^{\circ}$, inciso $\mathrm{X}$, da Constituição Federal de 1988 , haja vista que interfere na esfera privada ${ }^{89}$ e obriga a investigação de paternidade quando os interessados não a promoveram por si só.

A solução não seria atribuir ao parquet a legitimidade para propositura, mas sim prever que a mãe do recém-nato proporia a investigação de paternidade e, se ela negasse a postulação, fosse nomeado pelo juiz um tutor para preservar o interesse do menor e decidir sobre a propositura ou não da investigação de paternidade.

Procedendo-se desta forma, estaria assegurado que o interesse do filho seria preservado por ele mesmo, uma vez que o tutor iria representá-lo na ação investigatória de paternidade que poderia ser proposta pela Defensoria Pública, se insuficiente a situação financeira da mãe, ou se fosse movimentada a investigatória pelo tutor nomeado.

Em razão da previsão legal de inviolabilidade da vida privada, a investigação oficiosa afronta à Constituição e, concomitantemente, está de acordo com o princípio constitucional da paternidade responsável, verificando- se um confronto de normas constitucionais.

Contudo, os órgãos do Judiciário deverão constatar se o procedimento de ofício possui justificação, para indeferi-lo abinitio se a resposta for negativa, evitando com isso, de responsabilizar o Estado pelos danos causados ao particular na violação de sua privacidade.

89 E não se diga que a ação de investigação de paternidade promovida pela mãe em representação do filho teria o mesmo efeito, pois a legitimidade não estaria sendo atribuída a uma entidade dotada de custus legis, mas sim para as pessoas envolvidas com o vínculo de filiação. 
No mesmo sentido, Carlos Alberto Bittar $^{90}$ pondera que, tanto o Ministério Público, no momento de propor a investigatória, como o próprio Juiz, ao determinar a notificação do suposto pai indicado pela mãe, deverão tomar cuidado para não ofender direito personalíssimo, caso contrário, haveria a possibilidade do pai indicado demandar a reparação dos danos morais causados.

A fim de se esquivar desta lesão de direito, o citado doutrinador assevera que em ambas as hipóteses a decisão de agir deve ser baseada no juizo mais seguro possível sobre as declarações da mãe.

Outra inovação da Lei $n^{\circ} 8.560 / 92$ foi determinar que na própria sentença de primeiro grau reconhecedora da paternidade sejam fixados os alimentos provisionais ou definitivos do reconhecido que deles necessite. ${ }^{91}$

Sobre o ângulo doutrinário, cabe destacar o entendimento de Basílio de Oliveira, ${ }^{92}$ segundo o qual a igualdade de direitos entre os filhos impõe a abertura da investigação de paternidade para todos os filhos, inclusive os espúrios, opinião também do professor Luiz Edson Fachin, ${ }^{93}$ pelo qual o desenvolvimento do princípio da igualdade dos filhos consiste no direito de todos os filhos de verem declarada a verdadeira paternidade, o que implica na queda de todas as barreiras da ação investigatória para os filhos havidos fora do casamento.

No que tange às limitações da investigação, Humberto Theodoro Júnior $^{94}$ argumenta que deverão ser abertas possibilidades amplas de postulação e admitidos vários efeitos.

Possuem opinião favorável a que a investigação de paternidade se dê na constância da sociedade conjugal, Fábio Mario de Mattia ${ }^{95}$ e Mário Aguiar Moura, ${ }^{96}$ por sinal, posição corroborada pela jurisprudência indu-

90 Luiz Edson Fachin. "Reconhecimento de filho havidos fora do casamento". Répertório IOB de Jurisprudência. $2^{n}$ quinzena. maio. 1993. nº 10/93, p. 186-188.

91 Artigo $7^{\circ}$.

92 Basílio de Oliveira. O concubinato e a Constituição de 1988. Rio de Janeiro. Lumen Juris, 1992, p. XXI.

9.3 Luiz Edson Fachin, Estabelecimento..., op. cit.. p. 166.

94 Humberto Theodoro Júnior, "A nova Constituição e o Direito Civil". Jurisprudência Mineira, Belo Horizonte. 1989(106). p. 1-10.

95 Fábio Mário de Mottia. Investigação..., op. cit., Doutrina e página citada.

96 Mário Aguiar Moura. "A situação do fillho adulterino e a nova Constituição". in Repertório IOB de Jurisprudência, $1^{\text {a }}$ quinzena. n³/89, fev.. 1989, p. 51.

R. Fac. Direito. Curitiba, a.27. n.27. 1992/93. p.141-202 
bitavelmente aplicável, ${ }^{97}$ pois o que prepondera e deve mesmo preponderar é o interesse do filho.

Nossa opinião, conforme se expressou quando foi tratado do reconhecimento voluntário, é favorável a uma ampliação dos meios de prova, admitindo concomitantemente que todos os filhos, independente do estado civil ou parentesco dos genitores tenham declarada a verdadeira paternidade.

Em relação ao prazo, a investigatória deve ser mantida como o principal instrumento contra a verdade jurídica baseada em presunções incorretas. Essa ação de estado destinada a descobrir a verdade biológica, ora preponderante sobre as demais, não pode ser objeto de prescrição, assegurando-se, com a imprescritibilidade, que o pai, a mãe, o filho ou o terceiro interessado demande a investigatória.

A própria investigação, por sinal, se procedente e contrária ao termo de nascimento, deve ser acolhida de imediato para retificar o assento incorreto sob o aspecto da paternidade natural.

Dispensa-se a investigatória, quando a ação de alimentos, que tem por requisito de fundo o estabelecimento do vínculo de filiação, determine a respectiva relação.

Desta sorte, a ação de alimentos, que incoerentemente estava baseada no vínculo de filiação mas não operava o efeito mais importante, qual seja, estabelecer justamente a filiação, passa a ter papel determinador da paternidade.

Consoante este entendimento, a $4^{\text {a }}$ Câmara Cível do Tribunal de Justiça do Estado do Paraná decidiu que o vínculo de filiação pode ser provado na própria ação de alimentos.

97 Apelação cível - Investigação de paternidade - Carência da ação - Perquirição na constância do casamento do réu - possibilidade - art. $227, \S 6^{\circ}$, da cf $/ 88$ - óbice processual repelido. A novel Lex Fudamentalis, através do seu art. $227, \xi 6^{\circ}$, consagrou a igualdade de direitos entre os filhos havidos ou não da relação matrimonial, ou por adoção, ao mesmo tempo que proibiu todo tipo de discriminação contra os mesmos. Assim, a qualquer tempo poderão estes manejar a ação de investigação de paternidade (Tribunal de Justiça de Santa Catarina, $3^{\text {a }}$ Câmara Cível, Apelação Cível 37.942, Rel Des. Cid Pedroso. in Repertório IOB de Jurisprudência, RJ (3), 1993, $\left.\mathrm{n}^{\circ} 7267\right)$.

Ação de Alimentos - Propositura por Filho Ilegítimo - Reconhecimento da Paternidade 
A prova do vínculo de filiação na ação de alimentos, apesar de ser realizada incidentalmente, deve impedir que, para o reconhecimento judicial, tenha que se ajuizar uma nova ação, desta feita investigatória da paternidade, só não permitindo tal aplicação se o conjunto probatório for de tamanha fraqueza, que não autorize o efeito aqui pretendido.

Estas são as linhas que deverão ser traçadas para aplicar corretamente o princípio da igualdade de filiação na investigação de paternidade.

\section{Da ação de impugnação da paternidade}

O Código Civil denominou a ação pela qual o pai presumido nega o vínculo de paternidade como contestatória de paternidade, todavia, em virtude do confronto desta denominação com o direito processual civil, optou-se atualmente por chamá-la de impugnação da paternidade.

Visando romper com o vínculo de filiação, a ação de impugnação foi concebida para a utilização exclusiva do pai presumido, porém, como se não bastasse o monopólio marital para a impugnação, o legislador estabeleceu um prazo de dois meses para o seu exercício, além de determinar especificamente quais são as causas que podem ensejar a procedência da demanda.

Tal ação, se mantida como fora moldada no Código Civil e até o momento sem qualquer alteração, levaria o direito contemporâneo ao desprezo da verdade biológica, fator que iria permitir a soberania do conceito jurídico de filho sobre o natural.

\footnotetext{
- Alegação de Julgamento "extra petita" - Preliminar afastada - Pedido investigatório implícito e, além disso, aceito como objeto de ação pelas partes - Identifícação completa de filho havido ou não da relação do casamento no Registro de Nascimento Possibilidade - Igualdade na Filiação - Aplicação do art. $227 . \S 6^{\circ}$, da Constituição Federal - Mérito - Prova robusta e irrespondivel de paternidade - Prova pericial contundente, que chegou a oferecer índice de probabilidade de $98.9 \%$ - Menor que tem características do Réu - Semelhança física entre autor e Réu demonstrada na sentença Provas pessoais também convincentes - Pensionato do menor fixado de modo correto e compatível com a espécie ... 1. Operou-se com a Constituição Federal de 1988 (art. 227, $\S 6^{\circ}$ ) a igualdade jurídica dos filhos de qualquer espécie. 2. E a identificação completa de filho havido ou não da relação de casamento, no registro de nascimento, é dispositivo constitucional auto-aplicável (Apelação Cível n 0012404900 . Rel. Des. Ronald Accioly, julgamento em 15.05.91).
}

R. Fac. Direito, Curitiba, a.27, n.27, 1992/93, p.141-202 
A impugnação da paternidade volta-se contra o vínculo que a presunção de paternidade fixou em favor do marido da mãe.

Mas, diante do novo regramento, inclusive com a relativização da presunção de paternidade e, além do mais, pelo desejo de proteger o interesse do filho e a verdade biológica, as imposições limitadoras do direito anterior não podem mais vigorar.

Exige-se uma nova conformação legislativa, eliminando-se as limitações de outrora.

Desta maneira, o sistema de causas determinadas deve ser substituído por um sistema de livre produção probatória, ${ }^{99}$ a fim de possibilitar a derrubada da presunção, segundo as peculiaridades do caso concreto.

Quanto à legitimidade, para que o filho não seja prejudicado pela inércia proposital do pai presumido, poderá propor a demanda o próprio filho, a mãe, o pai presumido ou o biológico. 100

Especificamente sobre a legitimidade para a propositura da ação de impugnação da paternidade, José Ernani de Carvalho Pacheco ${ }^{101}$ aduz que seria do pai presumido e pessoas com interesses econômico ou moral, enquanto o professor Luiz Edson Fachin ${ }^{102}$ pretende atribuir a legitimidade ad causam para o marido, a mãe, o filho e terceiro.

Outrossim, para garantir a realização da verdade biológica, a impugnação deve abandonar o prazo exíguo do Código, para adotar a característica de imprescritibilidade, em virtude do primado da verdade biológica.

Por sinal, com a aplicação da presunção de paternidade para a união estável, também o pai concubinado terá a oportunidade de utilizar da impugnação de paternidade para provar estado contrário ao presumido.

99 Opção adotada pela Bélgica na reforma do seu sistema de filiação.

100 A Suiça, por exemplo, prevê a legitimidade ativa para a ação de impugnação da paternidade tanto para o pai presumido como para o filho.

101 José Enani de Carvalho Pacheco, "Da presunção de paternidade e da legitimidade para ação negatória", in Gazeta do Povo, 24.05.93, p. 9.

102 Luiz Edson Fachin, Estabelecimento..., op. cit., p. 167. 
No plano da igualdade, desde que concedida legitimação aos filhos para o exercício da ação, não é nem necessário mencionar que vedada está qualquer discriminação quanto a este futuro direito.

\section{Da posse do estado de filho}

Adotada no Código Civil de maneira tímida, como meio subsidiário de prova da filiação legítima, na falta do termo de nascimento, a posse do estado de filho deverá, necessariamente, ter um aperfeiçoamento no seu papel jurídico.

Representando a verdade sócio-afetiva, a posse do estado de filho compreende o nome atribuído ao filho, o tratamento do pai afetivo ao filho, pelo adjetivo de filho, e deste ao genitor pelo chamamento de pai, além do conhecimento social sobre o respectivo tratamento e aparência dos envolvidos no vínculo de filiação.

Como bem disse Luiz Edson Fachin, ${ }^{103}$ a evolução do princípio da igualdade entre as diferentes espécies de filiação atinge a sua conquista legislativa no momento em que as reformas recuperam a noção da posse do estado de filho.

Aplicada eficazmente no direito francês, a posse do estado de filho deve assumir um papel consolidador da presunção de paternidade ou, em caso de ser contrária à presunção, fragilizá-la para permitir o reconhecimento do filho pelo pai biológico, sem a necessidade de impugnar a paternidade presumida previamente.

Assinale-se que a posse do estado de filho, aplicada segundo a opção francesa, coibiria a possibilidade do filho escolher o seu pai, principalmente ao agir de má fé para obter vantagens econômicas.

Ora, se o filho foi concebido fora do casamento, mas sempre o pai presumido o tratou como tal, transformando-se em pai afetivo e sociológico, não é possível que ele utilize a impugnação de paternidade para estabelecer o vínculo de filiação com o pai biológico, somente porque este lhe daria melhores condições financeiras.

103 Luiz Edson Fachin, Estabelecimento..., op. cit., p. 149.

R. Fac. Direito, Curitiba, a.27, n.27. 1992/93. p.141-202 
Sendo assim, o papel estabilizador da presunção servirá de importante meio para impedir a má fé do filho ao impugnar a paternidade, ou seja, não será permitido que o próprio filho escolha quem é seu pai.

Tal posição é compartilhada por José Ernani de Carvalho Pacheco, ${ }^{104}$ o qual relata que a somatória da presunção com a posse do estado de filho veda a investigação da paternidade.

A solução do "conflito" de paternidade, por conseguinte, será a verificação dos elementos que compõem a posse do estado de filho, permitindo-se ao julgador uma aproximação com os dados contidos na realidade.

\section{Das antigas espécies de filhos}

Nesta etapa, antes de encerrar o estudo dos efeitos, com a abordagem dos direitos pessoais e patrimoniais dos filhos, serão realizadas algumas considerações acerca das categorias de filhos, a fim de estirpar as discriminações em matéria de filiação.

Os filhos naturais, decididamente os mais protegidos no sistema do Código, deixam de existir, passando a ser chamados de filhos havidos na união estável, exceto se não houver sequer concubinato, caso em que se chamariam filhos havidos fora do casamento e união estável, ausente em ambas as hipóteses qualquer discriminação.

A filiação adulterina, ${ }^{105}$ limitada na possibilidade de postular o reco-nhecimento, passa a ter amplitude do exercício da investigação de paternidade, inclusive com direito a uma proteção especial da família ou do Estado, como disciplinou o Estatuto da Criança e do Adolescente, em forma de revezamento, quando um destes responsáveis falhar no seu dever.

Os filhos incestuosos, ${ }^{106}$ por pior que seja a realidade, não podem ser objeto de diferenciação pelo ordenamento, devendo ter os mesmos direitos dos filhos havidos de um casamento, ou união estável.

104 José Enani de Carvalho Pacheco, Da presunção..., op. cit.

105 Classificação inconstitucional, por ser discriminatória, sendo aconselhável falar-se restritamente de filho havido no casamento ou na união estável, filho havido fora do casamento ou união estável, conforme os ascedentes formem ou não uma entidade familiar, Maiores informações, vide item VI. 
Para efeito de proteção, todavia, é necessário que nenhum documento mencione o avô paterno, da mesma forma que a investigação de paternidade deve se dar em absoluto segredo de justiça.

\section{Dos direitos pessoais e patrimoniais de todas as espécies de filhos}

No setor dos direitos pessoais, destacam-se o nome, pátrio-poder e guarda, os quais destinavam-se no Código Civil somente para os legítimos, legitimados e reconhecidos.

A Constituição, entretanto, estabeleceu a igualdade de direitos e o Estatuto da Criança e do Adolescente dividiu o dever entre a família, comunidade e poder público, de acordo com o artigo $4^{\circ}$.

Sendo assim, a eqüidade de tratamento dos filhos não deve ficar apenas no campo formal. Todos os filhos, sem exceção, sejam havidos dentro do casamento ou união estável, fora do casamento ou união estável, inclusive os filhos na família pós-nuclear, têm idênticos direitos aos antigos filhos legítimos.

O primeiro dos direitos pessoais atribuídos aos filhos consiste no próprio estado de filho, ou seja, aquele complexo de qualidades particulares valorizada pela sociedade, independentemente da origem. Cabe, ainda, a utilização do patronímico dos genitores, inclusive para o filho havido fora do casamento e união estável, em que um dos pais possua vínculo matrimonial com outra pessoa.

Com isto, os filhos antes chamados de adulterinos podem receber o nome de família e obter o respeito no meio social que o patronímico tiver.

O parentesco dos filhos, mesmo nos casos de incesto absoluto, nos quais, por exemplo, o pai é ao mesmo tempo avô e a mãe é irmã, será determinado sem qualquer vinculação ao repúdio social que esta relação proibida proporciona.

O maior obstáculo encontra-se, porém, na necessidade do filho ser acolhido na entidade familiar com respeito e compreensão, mas, se não 106 Denominação absolutamente inconstitucional. devendo-se designá-los apenas como filhos havidos fora do casamento e união estável. A respeito, vide item VI.

R. Fac. Direito. Curitiba. a.27. n.27. 1992/93, p.141-202 
houver disposição dos membros da família em realizar esta tarefa, o legislador deve prever meios subsidiários para alcançar o mesmo objetivo.

Além do mais, a igualdade dos filhos atribuiu aos genitores os direitos e deveres inerentes ao pátrio poder, devendo ser garantido o cumprimento da função precípua de proteger e assegurar o desenvolvimento da personalidade do filho, porém, o pátrio poder acaba se sujeitando à vontade dos genitores.

Os direitos pessoais dos filhos dependem demasiadamente da responsàbilidade dos pais para com estes, não havendo meios do Estado obrigar os genitores a fornecerem o amor, o carinho, a compreensão, o afeto e a solidariedade na hora precisa e na medida exata. ${ }^{107}$

$\mathrm{Na}$ esfera dos direitos patrimoniais, antigamente tão divergentes para as espécies de filhos, hoje terão na integralidade todos os direitos dos filhos legítimos.

Isso implica, principalmente, que todos os filhos, desde que fixado o vínculo de filiação, possuem direitos sucessórios, entrando para a classe dos herdeiros necessários, resultando no direito de preferência sobre os demais e a garantia de um quinhão.

Os alimentos, outro direito de essencial importância para os filhos, cabem para a integralidade destes, desde que identificado o genitor que deve prestá-lo.

Confirmando a necessidade de equiparação dos direitos patrimoniais, algumas decisões pretorianas já aplicaram-na ao caso concreto. ${ }^{108}$

107 Hildegard Taggesell Giostri, "Aspectos substanciais da posse do estado de filho na reforma francesa de 1972", Monografia apresentada à disciplina de Direito Civil II do Curso de Pós-Graduação em Direito da Universidade Federal do Paraná, Setor de Ciências Jurídicas, 1993.

108 Filiação - Direitos sucessórios - Reconhecimento judicial de filha do de cujus - Direito à sua cota em igualdade de condições em relação aos demais herdeiros - Cf/88 art. 227 , $\S 6^{\circ}-\mathrm{CCB}$, art. 1603 , I - Lei $883 / 49$, art. $2^{\circ}$. Tendo havido reconhecimento judicial de filha do de cujus, a mesma tem direito à sua cota em igualdade de condição em relação aos demais herdeiros (Tribunal de Justiça de São Paulo, Sexta Câmara Civil, Apelação Cível 106.227-1, Rel Des. Ernani Paiva, julgado em 1\%12/1988; in Jurisprudência Brasileira, v.147, Curitiba, Juruá, p. 294). Alimentos - Preliminar de nulidade rejeitada - Inteligência do $\S 6^{\circ}$, do artigo 227 da Constituição Federal de 1988 - Prova carreada aos autos inquestionável - Época da concepção coincidente com o relacionamento amoroso. Com a promulgação da nova Constituição Federal, foi afastada qualquer 
Não subsiste, por conseguinte, a discriminação em termos de direitos, para as classes de filhos ilegítimos, do direito pré-constituição, mas de todas as diferenciações apenas uma deve permanecer, se bem que não se trata de verdadeira discriminação. O normal andamento das relações familiares impede que o filho reconhecido ingresse no lar conjugal, quando o cônjuge não reconhecente desaprovar a medida, mantendo-se o artigo 359 do Código Civil em vigor.

Pensar o contrário seria afrontar a própria natureza humana, não se permitindo que o filho sofra os reflexos da indignação do cônjuge não reconhecente, o que prejudicaria o próprio desenvolvimento do filho, ao criar um clima de hostilidade na família nuclear.

A colocação numa família substituta se apresenta de melhor eficácia para a hipótese, proporcionando o desenvolvimento do filho, num ambiente de cunho verdadeiramente familiar.

\section{Conclusão}

Ficamos atrasados em demasia na regulamentação da relação jurídica entre pais e filhos, somente tendo caído as barreiras diferenciadoras com a Constituição Federal de 1988.

Não existe a menor sombra de dúvida, segundo nosso entendimento, que vivemos um período de eqüidade e consideração do valor da pessoa humana.

As modificações ao longo sugeridas expressam esta evidência, porém não basta aplicar tais pretensões no meio social.

De fato, em todos os institutos, observa-se uma nítida normatização voltada para a classe alta e média da sociedade, quase não havendo repercussão sobre a classe baixa da população, que em nosso país soma $60 \%$ (sessenta por cento) ou mais do total de pessoas.

discriminação relativa à filiação ilegítima. de acordo com o que estabelece o art. 227. $\S 6^{\circ}$ (Tribunal de Justiça do Paraná. Primeira Câmara Cível. Apelação Cível 577/89. Rel. Des. Osiris Fontoura, julgado em 31.10.89).

R. Fac. Direito. Curitiba. a.27. n.27. 1992/93. p.141-202 
Em artigo publicado no Jornal Folha de São Paulo, ${ }^{109}$ noticiava-se que no ano de 1993 a busca de pai desconhecido subira $80 \%$ (oitenta por cento), dado colhido junto ao Instituto de Medicina Social e Criminologia (Imesc) ${ }^{110}$ em São Paulo.

A constatação da triste realidade social se deu com tanta eficácia que transcrevemos o seguinte trecho:

O perfil de quem procura o Imesc é o da mãe solteira entre 30 e 40 anos de idade, classe baixa, cujo filho tem em média de três a quatro anÿs. Os virtuais pais variam entre 35 e 45 anos.

"Quase todas as mães querem que o pai pague a alimentação das crianças. Avalio o aumento dos exames como um dos sinais da crise do país", diz Antonio Luiz de Carvalho e Silva, 48, sociólogo e superintendente do Imesc.

Verifica-se, portanto, que a procura de uma paternidade para o filho é destinada, em sua maioria, a garantir somente a sobrevivência. Logo, a gama de efeitos que relatamos teria validade somente para as classes que efetivamente utilizam a justiça para concretizar suas pretensões insatisfeitas, quais sejam, a média e a alta.

Embora lamentável, a situação econômica e social das famílias e seus filhos está em colapso como muitos outros setores do país.

A única forma de evitar que a igualdade material dos filhos não fique somente instituída em termos ideais ou utópicos está na renovação dos governantes por outros indivíduos que tenham seriedade, capacidade e competência para tanto.

A diminuição dos gastos públicos, o incentivo à industrialização e agricultura, bem como o fornecimento de ensino de qualidade e saúde para toda a população, e não somente um terço dela, numa estimativa otimista, consistem os meios adequados para fazer da pretensão eqüitativa da filiação uma realidade, uma conquista do Brasil.

Em termos jurídicos, a nossa tarefa está cumprida, senão com brithantismo, pelo menos com seriedade.

109 Reportagem de Claudio Julio Tognolli, caderno cotidiano, 4 de abril de 1993.

110 De acordo com o artigo jornalístico, o único lugar do país que faz exames de paternidade gratuitamente. 
Aguardamos, no entanto, que as deficiências sociais sejam sanadas, para viabiliazar a aplicação das nossas propostas para todos os filhos deste país, bem como seja definido pelo legislador um novo sistema de direito de filiação, e não por meio de leis esparsas como vem ocorrendo.

\section{Referências Bibliográficas}

ALBUQUERQUE, Danielle Hidalgo Cavalcanti. "A filiação adulterina e o concubinato. Aspectos Constitucionais", Revista do Instituto dos Advogados do Paraná. 1989(14).

ALMEIDA, José Luiz Gavião de. "O novo estatuto da filiação". in O Direito de Familia na Nova Constituição. São Paulo: Saraiva. 1989.

BARROSO, Luis Roberto. "Igualdade perante a lei". Revista de Direito Público. São Paulo: $1986(78)$.

BASTOS, Celso Ribeiro; BRITTO, Carlos Ayres. Interpretação e aplicabilidade das normas constitucionais. São Paulo: Saraiva. 1982.

BEVILÁQUA, Clóvis. Direito de família. $9^{\mathrm{a}}$ edição. Rio de Janeiro: Livraria Freitas Bastos. 1959.

BITTAR, Carlos Alberto. "Reconhecimento de filhos havidos fora do casamento". Repertório IOB de Jurisprudência. $\mathrm{n}^{\circ} 10 / 93$. maio 1993.

BORGHI, Hélio. "A Situação dos filhos havidos fora do casamento e a nova Constituição". Revista dos Tribunais. 1989(643), p. 239-241.

CAHALI, Yussef Said. "A situação jurídica do filho nascido fora do casamento". Repertório IOB de Jurisprudência, $2^{a}$ quinzena, $\mathrm{n}^{\circ}$ 24/92. fevereiro/92.

CAMPOS, Diogo Leite de. Lições de direito de família e das sucessões. Coimbra: Livraria Almedina, 1990.

CARRAZZA, Roque Antonio. "O princípio da igualdade". Justitia. São Paulo, 1975(90).

CHAVES, Antonio, "Enciclopédia Saraiva do Direito". Verbete Filiação Espúria. v. 37. São Paulo: Saraiva, 1977.

"Filiação Legítima". Revista da Faculdade de Direito da USP. v. LXXIII, 1978.

CICU, Antonio. La filiación. $1^{a}$ edição. Madrid: Libreria General Victoriano Suárez, 1930.

CIMBALI, Enrico. A nova phase do direito civil em suas relações econômicas e sociais. Tradução Adherbal de Carvalho. Porto e Rio de Janeiro: Livraria Clássica e Chardron, 1900.

CORREA JUNIOR, Luiz Carlos de Azevedo. "Designações discriminatórias atinentes ao estado de filho: proibição e alteração do registro que as contenha". Revista Trimestral de Jurisprudência dos Estados. São Paulo, 1991(94).

COSTA. Dilvanir José da. "Aspectos do direito de família na nova Constituição". Revista dos Tribunais. 1988(635), p. 65-69.

R. Fac. Direito, Curitiba, a.27, n.27, 1992/93, p.141-202 
COSTA, Maria Isabel Pereira da. "A filiação e a nova Constituição Federal". Ajuris. Porto Alegre, 1989(45).

CUNHA, Sérgio Sérvulo da. Direito de família: mudanças. São Paulo: Ed. Revista dos Tribunais, 1987.

DANTAS, San Tiago. Direitos de familia e das sucessões. Revista e atualizada por José Gomes Bezerra Câmaro e Jair Barros. 2a edição. Rio de Janeiro: Forense, 1991.

DAYRELL, Carlos. Da filiação ilegítima no direito brasileiro: doutrina, jurisprudência, legislação. Rio de Janeiro: Forense, 1983.

DOMANSKI, Marcelo. "Algumas considerações acerca do reconhecimento espontâneo de filho não matrimonial na constância do casamento do pai em face da Constituição Federal de 1988 e da Lei ${ }^{\circ} 8.560 / 92 "$. Monografia semestral apresentada na disciplina de Direito Civil II do Curso de Pós- Graduação em Direito da Universidade Federal do Paraná, Setor de Ciências Jurídicas, em 07.06.93.

ESPÍNDOLA, Eduardo. A família no direito civil brasileiro. Rio de Janeiro: Conquista, 1957.

FACHIN, Luiz Edson. Estabelecimento da filiação e paternidade presumida. Porto Alegre: Fabris, 1992.

"Igualdade entre cônjuges". Gazeta do Povo. Curitiba. 08 de março de 1993.

FARIA, Anacleto de Oliveira. Do princípio da igualdade jurídica. São Paulo: Ed. Revista dos Tribunais/USP, 1973.

FELIPE, Jorge Franklin Alves. "A nova Constituição e seus reflexos no direito de família". Revista Forense. Rio de Janeiro, 1988(304).

FOWLER, Jussara Maria de Meirelles. "O princípio da igualdade entre as diferentes categorias de filhos". Jurisprudência Brasileira. Curitiba: Juruá, 1990.

FRANÇA, Rubens Limongi. Elementos de hermenêutica e aplicação do direito. São Paulo: Saraiva, 1984.

GARCEZ NETO, Martinho. Questões de família. Rio de Janeiro: Forense, 1944.

GOMES, Orlando. O novo direito de família. Porto Alegre: Sérgio Fabris Editor, 1984.

Direito de família. $7^{\mathrm{a}}$ edição. $2^{\mathrm{a}}$ tiragem. Rio de Janeiro: Forense, 1990.

GIOSTRI, Hildegard Taggesell. "Aspectos substancias da posse do estado de filho na reforma francesa de 1972". Monografia apresentada à disciplina de Direito Civil II do Curso de Pós-Graduação em Direito da Universidade Federal do Paraná, Setor de Ciências Jurídicas, 1993.

MATTIA, Fábio Mário de. "Investigação de paternidade: alimentos, filiação e conseqüências da nova norma constitucional". Repertório IOB de Jurisprudência. $\mathrm{n}^{\circ} 3 / 89,1^{\text {a }}$ quinzena de fevereiro, 1989.

MAXIMILIANO, Carlos. Hermenêutica e aplicação do direito. $9^{\mathrm{a}}$ edição. $1^{\mathrm{a}}$ tiragem. Rio de Janeiro: Forense, 1980.

MELLO, Celso Antônio Bandeira de. O conteúdo jurídico do princípio da igualdade. São Paulo: Ed. Revista dos Tribunais, 1978.

MIRANDA, Pontes de. Tratado de direito de família. $3^{a}$ edição. São Paulo: Max Limonad, 1947. 

1977.

Democracia, liberdade, igualdade: os três caminhos. $2^{a}$ edição. São Paulo: Saraiva.

MOURA, Mário Aguiar. "A situação do filho adulterino e a nova Constituição". Repertório $I O B$ de Jurisprudência, $1^{\text {a }}$ quinzena, $\mathrm{n}^{\circ} 3 / 89$. fevereiro de 1989.

Tratado prático da filiação. $2^{\text {a }}$ edição., vol. III, Rio de Janeiro: Aide, 1984.

MUNIZ. Francisco José Ferreira. "O direito de família na solução dos litígios". Conferência proferida no XII Congresso Brasileiro de Magistrados. separata, Curitiba: março de 1992.

OLIVEIRA, Basílio de. O concubinato e a Constituição de 1988. Rio de Janeiro: Lumen Juris, 1992.

OLIVEIRA, Guilherme. "Sobre a verdade e a ficção no direito de família". Boletim de Faculdade de Direito de Coimbra. 1975.

OLIVEIRA. Lamartine Correa de; MUNIZ, Francisco José Ferreira. Direito de família (direito matrimonial). Porto Alegre: Sérgio Fabris Editor. 1990.

OLIVEIRA, Wilson de. Direito de família. Rio de Janeiro: Forense, 1985.

PACHECO, José Ernani de Carvalho. "Da presunção de paternidade e da legitimidade para ação negatória". Gazeta do Povo. Curitiba, 24.05.93. p. 9.

PEREIRA, Áurea Pimentel. A nova Constituição $e$ o direito de família. Rio de Janeiro: Renovar, 1989.

PEREIRA. Caio Mário da Silva. Reconhecimento de paternidade e seus efeitos. $3^{a}$ edição. Rio de Janeiro: Forense, 1991.

Instituições de direito civil. $3^{\text {a }}$ edição. Rio de Janeiro: Forense, 1985.

PEREIRA. Sérgio Gischkow. "Tendências modernas do direito de familia". Revista da Faculdade de Direito da Universidade Federal de Uberlândia. 1989(18), p. 295-323.

"Algumas questões de direito de família na nova Constituição". Revista dos Tribunais $1989(636)$.

PIMENTA, José da Costa. Filiação. Coimbra Editora: Coimbra, 1986.

RODRIGUES, Sílvio. Direito civil. Direito de Família. $5^{\text {a }}$ edição. São Paulo: Saraiva, 1977.

ROSA, Edgard Lincoln de Proença. "Aspectos do princípio da igualdade". Revista de Informação Legislativa. Brasília, 1981(71).

ROSSI, Celso Antonio. "Da possibilidade de reconhecimento do filho incestuoso". Revista da Associação dos Magistrados do Paraná. Curitiba, 1981(25).

SANTOS, J. M. de Carvalho. Código civil brasileiro interpretado - direito de familia. $9^{\mathrm{a}}$ edição. São Paulo: Livraria Freitas Bastos, 1963.

SILVA, José Afonso da. Curso de direito constitucional positivo. $6^{\text {a }}$ edição. São Paulo: Ed. Revista dos Tribunais. 1990.

Aplicabilidade das normas constitucionais. $2^{\text {a }}$ edição. São Paulo: Ed. Revista dos Tribunais, 1982.

THEODORO Junior, Humberto. "A nova Constituição e o Direito Civil". Jurisprudência Mineira. Belo Horizonte, 1989(106).

TOGNOLI, Claudio Julio. "A busca do pai desconhecido sobe $80 \% "$. Folha de São Paulo. Caderno Cotidiano, 4 de abril de 1993,p. 1.

R. Fac. Direito. Curitiba, a.27,n.27.1992/93.p.141-202 
VIANA, J. de Segadas; GALVÃo, Francisco. A lei de proteção da família. Rio de Janeiro: Livraria Jacinto, 1942.

VIEGAS, João Francisco Moreira. "A filiação fora do casamento na nova Carta da República". Revista dos Tribunais. São Paulo, 1988(634).

VILLELA, João Baptista. "Reconhecimento da paternidade entre o pós-moderno e o arcaico". Repertório IOB de Jurisprudência. $\mathrm{n}^{\circ} 4 / 93$, fev. 1993.

. "Casamento e família na futura constituição brasileira: a contribuição alemã". Revista Informação Legislativa. Brasília, 1987(96).

WALD, Amoldo. Direito de família. $7^{\mathrm{a}}$ edição. $2^{\mathrm{a}}$ tiragem, São Paulo: Ed. Revista dos Tribunais, 1990. 